
NATIONS

\title{
LIST OF LIBRARY PUBLICATION
}

FAO Technical Information Section December, 1998 


\section{Extension}

\begin{tabular}{|c|c|c|c|c|}
\hline S. No & Author & Topic & $\begin{array}{l}\text { Year of } \\
\text { Publish }\end{array}$ & $\begin{array}{l}\text { No of } \\
\text { copies }\end{array}$ \\
\hline 1 & FAO /UNDP & Agricultural Extension training Baseline survey Report & 1990 & 1 \\
\hline 2 & FAO / UNDP & Strengthing Agricultural Extension in Nigeria & Oct-90 & 3 \\
\hline 3 & FAO & Guide to Extension Training & 1985 & 1 \\
\hline 4 & FAO/UNDP & Workshop in Extension Training principles and methods. & Dec-90 & 2 \\
\hline 5 & FAO/UNDP & Strengthing Agricultural Extension in Nigeria & 1991 & 1 \\
\hline 6 & Geoffery Moss and Don Tre Adwell & Teaching Extension Skills & 1977 & 2 \\
\hline 7 & Fisher J.D. & Agricultural extension Training & 1970 & 1 \\
\hline 8 & FAO & Global Consultation on Agricultural Extension & 1989 & 2 \\
\hline 9 & FAO / UNDP & Strengthing Agricultural extension in Nigeria & 1990 & 2 \\
\hline 10 & EKPERE J.A & Agricultural Extension & 1990 & 1 \\
\hline 11 & GTZ & $\begin{array}{l}\text { A Summary of the Process and Evaluation Results of the Strategic Extension Compaign on Rat } \\
\text { control in Bangladesh }\end{array}$ & 1987 & 1 \\
\hline 12 & FAO & $\begin{array}{l}\text { A Summary of the Process and Evaluation Results of the Strategic Extension Compaign on } \\
\text { Integrated weed management in muda Irrigation scheme Malaysia }\end{array}$ & 1989 & 1 \\
\hline 13 & Barbara Frok Program & Work bookfor Conducting Program Evaluation by Country and State Extension Staff & 1989 & 2 \\
\hline 14 & FAO & Effectiveness of Agricultural Extension Services in Reaching Rural Women in Africa & 1987 & 1 \\
\hline 15 & FAO & $\begin{array}{l}\text { Report of the Workshop on Improving Administration and Management of Agricultural Extension } \\
\text { Survices in African Countries }\end{array}$ & Sep-87 & 1 \\
\hline 16 & FAO/UNDP & Report on the Zonal Workshop on extension Strategies for Reaching Rural Women in Zonelll & Oct-90 & 1 \\
\hline 17 & FAO & $\begin{array}{l}\text { Integrating environmental and Sustainable development themes in to Agricultural Education and } \\
\text { extension Programs }\end{array}$ & 1993 & 2 \\
\hline 18 & FAO / UNDP & Strengthing Agricultural Extension in Nigeria & 1991 & 1 \\
\hline 19 & Shastry U.S. SKT Willians et al & $\begin{array}{l}\text { A Mid Term Evaluation of the Agricultural extension Research Project for the Small Farmers in the } \\
\text { Communal Areas of Zimbabwe }\end{array}$ & 1986 & 1 \\
\hline 20 & $\mathrm{FAO}$ & A study of the Agricultural extension Experiences & 1984 & 1 \\
\hline 21 & $\begin{array}{l}\text { United States Department of Agriculture and } \\
\text { State Land, Grant Universities Cooperating }\end{array}$ & Evaluating Extension Work & Oct-76 & 1 \\
\hline 22 & $\begin{array}{l}\text { United States International Cooperation } \\
\text { Administration }\end{array}$ & Using Visuals in Agricultural extension progress & Jul-67 & 1 \\
\hline 23 & FRED P. FRUT CHEY & Evaluation in Extension & 1967 & 1 \\
\hline 24 & $\begin{array}{l}\text { Glenormistion Agricultural College, Noorat } \\
\text { Victoria }\end{array}$ & Australian Agricultural Extension Conference & 1973 & 1 \\
\hline 25 & UNDP & $\begin{array}{l}\text { An Organizational Analysis of Agricultural extension and Related Programs in the People's } \\
\text { Republic of Bangladesh }\end{array}$ & 1978 & 1 \\
\hline
\end{tabular}




\begin{tabular}{|c|c|c|c|c|}
\hline$\Sigma 6$ & $\begin{array}{l}\text { Faculty of Agriculture and Forestry, } \\
\text { University of Melbourne }\end{array}$ & Melbourne Notes on Agricultural extension & 1979 & 1 \\
\hline 27 & Department of Agriculture Vectoria, Australia & Melbourne Notes on Agricultural extension & 1981 & 1 \\
\hline 28 & Department of Agriculture Vectoria, Australia & A Manual for Agricultural extension Workers in Nigeria & 1984 & 1 \\
\hline 29 & S.K. Taiwo Williams et al & Guidelines for Planning extension Programs & 1984 & 1 \\
\hline 30 & UNDP / DTCP & Agricultural Extension Systems in Some African And Asian Countries & 1984 & 1 \\
\hline 31 & FAO & Improving Agricultural Extension to Increase Food Production in Africa & 1986 & 1 \\
\hline 32 & FAO & Participatory Approaches of Agricultural Extension & 1987 & 1 \\
\hline 33 & A.U.I.D.P & A Course Manual in Agricultural and Livestock Extension, Rural Sociology & 1982 & 1 \\
\hline 34 & A.U.I.D.P & A Course Manual in Agricultural and Livestock Extension, The Extension Process & 1982 & 1 \\
\hline 35 & $\begin{array}{l}\text { American Institute of Agricultural Sciences of } \\
\text { the O.A.S Turrialba, Costa Rica }\end{array}$ & Visual Aids in Agricultural Extension & Jul-57 & 1 \\
\hline 36 & Digital Communication (Pvt. LTD) & DCX-24 Plus Extension User Manual & $?$ & 1 \\
\hline 37 & E.S. MALINDI & Agricultural Extension and Training Policy & 1988 & 1 \\
\hline 38 & FAO / UNDP & Extension Delivery to Rural Women by Women in Development & Jul-90 & 1 \\
\hline 39 & FAO & Research and Extension in Effectives Water Use at the Farm Level in the Near East Region & 1994 & 1 \\
\hline 40 & FAO & $\begin{array}{l}\text { Integrating Environmental and Sustainable Development Themes in to Agricultural Education and } \\
\text { Extension Programs }\end{array}$ & 1993 & 1 \\
\hline 41 & FAO / UNDP & Extension Strategies for Reaching Rural Women & 1990 & 1 \\
\hline 42 & FAO / UNDP & $\begin{array}{l}\text { Niger State Agricultural Development Project Zonal Workshop on Extension Strategies for } \\
\text { Reaching Rural Women }\end{array}$ & 1990 & 1 \\
\hline 43 & FAO Project TCP / SRL & Extension Methods and Techniques & $?$ & 1 \\
\hline 44 & UNIVERSITY OF MELBOURNE & An Evaluation of the Role of Extension in the Australian PIG Industry & 1978 & 1 \\
\hline 45 & Dr. B.B. SCOULLAR & Guides to Agricultural Extension Program Planning and Program Management & 1988 & 1 \\
\hline 46 & FAO / UNDP & Report on the Zonal Workshop on Extension Strategies for Reaching Rural Women & 1990 & 1 \\
\hline
\end{tabular}

\section{Agriculture}

\begin{tabular}{|c|c|}
\hline 47 & FAO \\
\hline 48 & FAO \\
\hline 49 & FAO \\
\hline 50 & FAO \\
\hline 51 & UNDP \\
\hline 52 & FAO / UNDP \\
\hline 53 & FAO \\
\hline 54 & FAO \\
\hline 55 & $\mathrm{FAO}$ \\
\hline 56 & FAO \\
\hline
\end{tabular}

Agricultural Taxation in Ethiopia

Agricultural Taxation in Developing Countries

Agricultural Taxation Under Structural Adjustment

Agricultural Credit

Sustainable Human Development and Agriculture

women in Agriculture

The Role of Universities in national Agricultural Research Systems

Food And Agricultural Legislation

Food And Agricultural Legislation

Priorities for Major Program Agriculture in 1994-95

\begin{tabular}{|l|c|}
\hline 1992 & 9 \\
\hline 1993 & 1 \\
\hline 1994 & 1 \\
\hline 1995 & 1 \\
\hline 1994 & 1 \\
\hline 1990 & 1 \\
\hline 1993 & 1 \\
\hline Dec-92 & 12 \\
\hline Dec-94 & 1 \\
\hline Feb-93 & 1 \\
\hline
\end{tabular}




\begin{tabular}{|c|c|c|c|c|}
\hline 57 & FAO & Statistics on Agricultural Support Price $1983-\overline{92}$ & 1993 & 2 \\
\hline 58 & UNDP / FAO & Agriculture, Forestry and Fisheries & 1996 & 1 \\
\hline 59 & FAO & Economic management of Administered Agricultural Pricing and Payment Systems in Africa & 1993 & 2 \\
\hline 60 & FAO & Pesticide Application Equipment for use in Agriculture & 1995 & 1 \\
\hline 61 & FAO & Waste Water Treatment and use in Agriculture & 1992 & 1 \\
\hline 62 & FAO & Economic Management of Administered Agricultural Pricing and Payment Systems in Africa & 1993 & 1 \\
\hline 63 & FAO & World Agriculture & 1995 & 1 \\
\hline 64 & FAO & Methods of Microlevel Analysis for Agricultural Programs and Policies & 94 & 1 \\
\hline 65 & FAO & Structural Adjustment and Agriculture & 94 & 1 \\
\hline 66 & FAO & Transition and Price Stabilization Policies in East European Agriculture & 94 & 1 \\
\hline 67 & $\mathrm{FAO}$ & The Management of Agricultura! Schools and Colleges & 1985 & 1 \\
\hline 68 & $\mathrm{FAO}$ & Farm and Community information Use for Agricultural Programs and Policies & 1994 & 1 \\
\hline 69 & FAO & World Census of Agriculture & 1992 & 4 \\
\hline 70 & FAO & Agro-Ecological Land Resources Assessment for Agricultural Development Planning & 1991 & 4 \\
\hline 71 & FAO & Computerized Systems of Land Resources Appraisal for Agricultural Development & 1993 & 2 \\
\hline 72 & FAO & Agricultural Engineering in Development & 1994 & 1 \\
\hline 73 & FAO & Agricultural Engineering in Development & 1992 & 3 \\
\hline 74 & FAO & Agricultural Price Policy & 1992 & 1 \\
\hline 75 & FAO & Committee on Agriculture & 1993 & 7 \\
\hline 76 & FAO & Agro-Ecological Land Resources Assessment for Agricultural Development Planning & 1992 & 1 \\
\hline 77 & FAO & Agro-Ecological Land Resources Assessment for Agricultural Development Planning & 1991 & 1 \\
\hline 78 & FAO & Organization and Management of Agricultural Services for Small Formers of Eastern Europe & 1994 & 1 \\
\hline 79 & FAO & $\begin{array}{l}\text { Waste Water Management for Agricultural Production and Environmental Protection in the Near } \\
\text { East Region }\end{array}$ & 1995 & 1 \\
\hline 80 & CTA / DSE / GTZ / DLG & Agriculture Rural Development & 1995 & 1 \\
\hline 81 & FAO & $\begin{array}{l}\text { Wastewater Management for Agricultural Production and Environmental Protection in the near } \\
\text { East Region }\end{array}$ & 1995 & 1 \\
\hline 82 & $\mathrm{FAO}$ & Impact of the Uruguay Round on Agriculture & 1995 & 1 \\
\hline 83 & L. LOFTUS and J. W. CARY & To Wards an Understanding of Management Education in Agriculture & 1980 & 1 \\
\hline 84 & C.A. UNDERWOOD and P.W. Salmon & Nature and Extent of Self Directed Learning in Agriculture & 1980 & 1 \\
\hline 85 & N.F. BARR and E.F. ALMOYND & The Agricultural Work Force in Victoria & 1981 & 1 \\
\hline - 86 & $\mathrm{FAO}$ & Prevention of Water Pollution by Agriculture and Related Activities & 1993 & 1 \\
\hline 87 & FAO & FAO Participation in Sustainable Agriculture and Rural Development in Pakistan & 1994 & 1 \\
\hline 88 & FAO & Agricultural Investment to Promote Improved Capture and Use of Rainfall in Dryland Farming & 1995 & 1 \\
\hline 89 & FAO & Selection Testing and Evaluation of Agricultural Machines and Equipment & 1995 & 1 \\
\hline 90 & $\mathrm{FAO}$ & Japanese Agriculture & $?$ & 1 \\
\hline 91 & FAO & Agricultural Biotechnology in the Developing World & 1995 & 1 \\
\hline 92 & CPAG & Agriculture Science & 1994 & 1 \\
\hline 93 & CPAG & Agricultural Science & 1995 & 1 \\
\hline 94 & FAO & Investment in Agriculture: Evaluation and Prospects & 1995 & 1 \\
\hline 95 & FAO & Training of Main Power for Agricultural and Rural Development in Africa & 1984 & 1 \\
\hline 96 & $\mathrm{FAO}$ & FAO Participation in Sustainable Agriculture and Rural Development in Pakistan & 1996 & 1 \\
\hline 97 & $\mathrm{FAO}$ & Water Harvesting for Improved Agricultural Production & 1994 & 1 \\
\hline
\end{tabular}




\begin{tabular}{|c|c|c|c|c|}
\hline 98 & CTA / DSE / GTZ / DLG & Agriculture Rural Development & 1995 & 1 \\
\hline 99 & FAO & Japanese Agriculture & $?$ & 1 \\
\hline 100 & FAO & Selected Issues in Agricultural Policy Analysis in the Near East & 1995 & 1 \\
\hline 101 & FAO & Medium-Term Prospects for Agricultural Commodities & 1994 & 2 \\
\hline 102 & FAO & Testing and Evaluation of Agricultural Machinery and Equipment & 1994 & 2 \\
\hline 103 & FAO & Agriculture Engineering in Development & 1993 & 1 \\
\hline 104 & IAEA & Manual On Measurement of Methane and Nitrous Oxide Emissions from Agriculture & 1992 & $\overline{2}$ \\
\hline 105 & FAO & Agriculture: Towards 2010 & 1993 & 4 \\
\hline 106 & $\mathrm{FAO}$ & AGRICULTURE PRICE POLICY & 1992 & 1 \\
\hline 107 & $\mathrm{FAO}$ & Food Nutrition and Agriculture & 1993 & 5 \\
\hline 108 & FAO & $\begin{array}{l}\text { Training Courses in the Execution and Implementation of Agricultural Technical Cooperation } \\
\text { Projects }\end{array}$ & 1998 & 1 \\
\hline 109 & The Swedish Committee For Afghanistan & The Agriculture Survey of Afghanistan 1992-93 & 1993 & 1 \\
\hline 110 & The Swedish Committee for Afghanistan & The Agricultural Survey of Afghanistan & 1990 & 1 \\
\hline 111 & FAO & New Directions for Agriculture Forestry and Fisheries & 1994 & 1 \\
\hline 112 & FAO & Inland Fisheries Under the Impact of Irrigated Agriculture & 1995 & 1 \\
\hline 113 & FAO & Near East Regional commission on Agriculture & 1993 & 3 \\
\hline 114 & $\mathrm{FAO}$ & The Scheme for Agricultural Credit Development (SACRED) & 1995 & 1 \\
\hline 115 & FAO & Evaluation of Four Agricultural Projects & 1994 & 1 \\
\hline 116 & FAO & Improving Gender Disagg Ye G $F^{\dagger}$ Data on Human Resources Through Agricultural Confuses & 1992 & 1 \\
\hline 117 & FAO & $\begin{array}{l}\text { Toward Improved Multilevel Planning for Agricultural and Rural Development in Asia and the } \\
\text { Pacific }\end{array}$ & $?$ & 1 \\
\hline-118 & FAO / UNDP & Women in Agriculture & 1990 & 1 \\
\hline 119 & UNIVERSITY OF MELBOURNE & Agricultural extension Research Project Abstracts & 1978 & 1 \\
\hline-120 & FAO & Food, Nutrition and Agriculture & 1994 & 1 \\
\hline 121 & FAO & Evaluation of Four Agricultural Projects & 1994 & 1 \\
\hline 122 & FAO & $\begin{array}{l}\text { Agriculture Non-Agriculture Interactions and the Impact of Stabilization and Structural Adjustment } \\
\text { Programs }\end{array}$ & 1987 & 1 \\
\hline 123 & FAO & The Theoretical and Empirical Analysis of Agricultural Trade of LDCS & 1991 & 1 \\
\hline 124 & FAO & LA SITUATION MONDIALE DE L'A LIMINATION ET DE L'AGRICULTURE & 1993 & 3 \\
\hline 125 & FAO & THE STATE OF FOOD AND AGRICULTURE & 1995 & 1 \\
\hline 126 & $\mathrm{FAO}$ & THE STATE OF FOOD AND AGRICULTURE & 1993 & 9 \\
\hline 127 & FAO / UNDP & Evaluation of Four Agricultural Projects & 1994 & 1 \\
\hline-128 & FAO & Food Nutrition and Agriculture & 1995 & 1 \\
\hline 129 & FAO & Food Nutrition and Agriculture & 1994 & 1 \\
\hline 130 & FAO & FAO Participation in Sustainable Agriculture and Rural Development in Pakistan & Oct-94 & 1 \\
\hline-131 & FAO & Guidelines For The Design of Agricultural Investment Projects & 1995 & 1 \\
\hline$\therefore 132$ & FAO & Agricultural Taxation in Developing Countries & 1993 & 1 \\
\hline 133 & FAO /UNESLO /ILO & Training for Agriculture and Rural Development & 1976 & 1 \\
\hline 134 & FAO /UNESW/ILO & Training for Agriculture and Rural Development & 1983 & 1 \\
\hline 135 & FAO & Genie Agricole Et Developpement & 1993 & 1 \\
\hline 136 & FAO & $\begin{array}{l}\text { Promouvoir La Participation Du Secteure Prive A La Commercialisation Des Produits Agricoles En } \\
\text { Afrique }\end{array}$ & 1993 & 1 \\
\hline
\end{tabular}




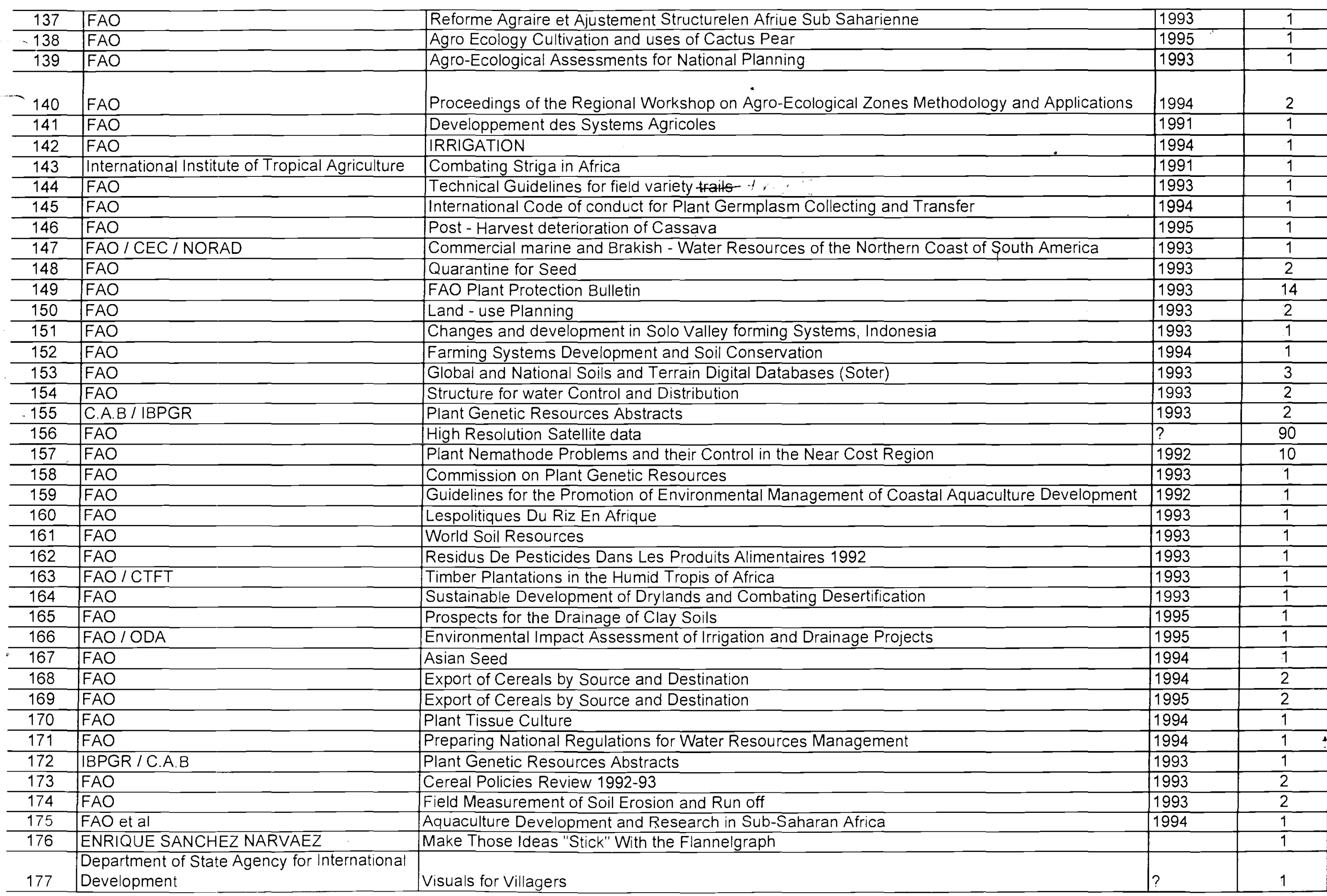




\begin{tabular}{|c|c|}
\hline 178 & HELEN STROW \\
\hline 179 & J.Mc ALLISTER and M. WALKER \\
\hline 180 & N.F. BARR and E.F. ALMOND \\
\hline 181 & P.W. SALMON \\
\hline 182 & BARRIE BARDSLEY \\
\hline 183 & N.F. BARR, R.E.WESTON and J.W. CARY \\
\hline 184 & PETER W. SALMON \\
\hline 185 & R.E WESTON and J.W. CARY \\
\hline 186 & FAO \\
\hline 187 & FAO \\
\hline 188 & FAO \\
\hline 189 & FAO \\
\hline 190 & UNITED NATIONS \\
\hline 191 & FAO / GASGA \\
\hline 192 & EFNEPS et al \\
\hline 193 & FAO \\
\hline 194 & FAO \\
\hline 195 & FAO \\
\hline 196 & FAO \\
\hline 197 & FAO \\
\hline 198 & $\mathrm{FAO}$ \\
\hline 199 & FAO \\
\hline 200 & FAO \\
\hline 201 & $\mathrm{FAO}$ \\
\hline 202 & FAO \\
\hline 203 & $\mathrm{FAO}$ \\
\hline 204 & $\mathrm{FAO}$ \\
\hline 205 & $\mathrm{FAO}$ \\
\hline 206 & FAO \\
\hline 207 & SPC \\
\hline 208 & FAO \\
\hline 209 & FAO \\
\hline 210 & FAO \\
\hline 211 & $\mathrm{FAO}$ \\
\hline 212 & TITA \\
\hline 213 & Luis Ramiro Beltran \\
\hline 214 & U.S. Department of Agriculture \\
\hline 215 & FAO \\
\hline 216 & FAO \\
\hline 217 & FAO \\
\hline
\end{tabular}

Showing How the Demonstration Teaching Method

Rural Work Force and Population in Victoria

The Third Way

Personal Psychology of Change in Management

Formers Assessment of Information and its Sources

Formers Looking to the Future

A Psychological Investigation of Farm Management Education

A CHANGE FOR THE BETTER?

Irrigation in the Near East Region in Figures

Irrigation Water Delivery Models

Irrigation in Africa in Figures

FAO Seed Review 1989 - 1994

Earth Summit

Grain Storage Techniques

Supervision and Management of EFNEP

Mangosteen Cultivation

Quality Declared Seed

Social and Economic Incentives for Small Holder Tree Growing

Maize

Planning for Sustainable Use of Land resources

FAO Plant Protection Bulletin

Ran Butan Cultivation

Tropical Root and Tuber Crops

Serial Polices Review 1994 - 95

Serial Polices Review 1993-94

Eradicating the Screw Worm

Green Manuring for Soil Productivity in Proverment

Asian Watmavet

Learning form Experience

Improving Land Tenure

Selecting Tree Species on the Basis of Community needs

Ninth Meeting of the East and Southern African Sub-Committee for Soil Correlation and Land

Evaluation

A Historical Review of the Major Graft-Transmissible Disease of Citrus

Tree and Land Tenure

Soybeans for Good Health

Puppets Go to the Country **

Irrigation Methods Crops and Practices Using Wastewater

Wastewater Use and Human Health

Treatment of Wastewater Used for Irrigation

1980

1981

1981

1982

1980

1980

1979

1997

1994

1995

1994

1992

1994

1979

1995

1993

1987

1995

1994

1994

1994

1995

1994

1992

1994

1995

1995

1975

1995

1992

1995

1995

1989

?

1965

1992

1991

1992 


\section{Fisheries}

\begin{tabular}{|c|c|}
\hline 218 & $\mathrm{FAO}$ \\
\hline 219 & $\mathrm{FAO}$ \\
\hline 220 & $\mathrm{FAO}$ \\
\hline 221 & $\mathrm{FAO}$ \\
\hline 222 & $\mathrm{FAO}$ \\
\hline 223 & FAO \\
\hline 224 & $\mathrm{FAO}$ \\
\hline 225 & $\mathrm{FAO}$ \\
\hline 226 & $\mathrm{FAO}$ \\
\hline 227 & FAO \\
\hline 228 & $\mathrm{FAO}$ \\
\hline 229 & FAO \\
\hline 230 & $\mathrm{FAO}$ \\
\hline 231 & FAO \\
\hline 232 & $\mathrm{FAO}$ \\
\hline 233 & $\mathrm{FAO}$ \\
\hline 234 & $\mathrm{FAO}$ \\
\hline 235 & $\mathrm{FAO}$ \\
\hline 236 & $\mathrm{FAO}$ \\
\hline 237 & $\mathrm{FAO}$ \\
\hline 238 & $\mathrm{FAO}$ \\
\hline 239 & $\mathrm{FAO}$ \\
\hline 240 & $\mathrm{FAO}$ \\
\hline 241 & $\mathrm{FAO}$ \\
\hline 242 & FAO \\
\hline 243 & FAO \\
\hline 244 & FAO \\
\hline 245 & FAO \\
\hline 246 & FAO \\
\hline 247 & FAO \\
\hline 248 & FAO \\
\hline 249 & FAO \\
\hline 250 & FAO \\
\hline 251 & FAO \\
\hline 252 & $\mathrm{FAO}$ \\
\hline 253 & $\mathrm{FAO}$ \\
\hline 254 & FAO \\
\hline 255 & FAO \\
\hline 256 & FAO \\
\hline
\end{tabular}

Seminar on Credit for Antisanal Fisheries in West Africa

World Fisheries and Aquaculture

Committee for Inland Fisheries of Africa

General Fisheries Council for the Mediterranean

Workshop on Fishery Statistics for Estonia, Latvia and Lithuania

FAO Fisheries Software

Structure and Process of the 1993-1995 United Nation Conference on Straddling Fish Stocks and

Highly Migratory Fish Stocks

INDO-PACIFIC FISHERY COMMISSION

Consultation on the Establishment of a Fisheries Credit Network for Africa and the Pacific

Technical Consultation on the Code of conduct for Responsible Fishing

Coordinating Working Party on Atlantic Fishery Statistics

Indo-Pacific Fishery Commission, Working Party of Experts on Inland Fisheries

Expert Consultation on Guidelines for Responsible Fisheries Management

Review of the State of World Fishery Resources

Reservoir Fisheries of India

Economic Engineering Applied to the Fishery Industry

Genetic Diversity of Marine Fisheries Resources

Chronicles of Marine Fishery Landings $(1950-1994)$

Fishery Statistics

Fishery Statistics

Bulletin of Fishery Statistics

General Fisheries Council for The Mediterranean

Fishing Doat Construction:3

Overview of World Elasmobranch Fisheries

An Introduction to Monitoring, Control and Surveillance Systems for Capture Fisheries

Chronicles of Marine Fishery Landings (1950 - 1994)

Reference Points for Fisheries Management

A Review of Operational Interations Between Pinnipeds and Fisheries

Socio-Economic Surveys in Fisheries in Africa an Annotated bibliography

INDO-PACIFIC FISHERY COMMISSION

Fish Marketing Distribution and Trade in the Islamic Republic of Iran

Fishery Committee for the Eastern Contral Atlantic

Western Central Atlantic Fishery commission

Committee on Fisheries

Marketing in Fisheries a Selective Annotated Bibliography

Responsible Fisheries

Water Quality and Fish Health

General Fisheries Council for the Mediterranean

Report of the AD HOC Consultation on the Role of Regional Fishery Agencies in Relation to High

Seas Fishery Statistics

\begin{tabular}{|l|l}
\hline 1994 & 1 \\
\hline 1995 & 1 \\
\hline 1994 & 1 \\
\hline 1994 & 1 \\
\hline 1995 & 1 \\
\hline 1995 & 1 \\
\hline & \\
\hline 1995 & 1 \\
\hline 1995 & 3 \\
\hline 1995 & 1 \\
\hline 1995 & 1 \\
\hline 1995 & 1 \\
\hline 1994 & 1 \\
\hline 1995 & 2 \\
\hline 1997 & 1 \\
\hline 1995 & 1 \\
\hline 1995 & 1 \\
\hline 1994 & 1 \\
\hline 1996 & 1 \\
\hline 1992 & 2 \\
\hline 1993 & 2 \\
\hline 1994 & 1 \\
\hline 1995 & 1 \\
\hline 1995 & 1 \\
\hline 1994 & 1 \\
\hline 1994 & 1 \\
\hline 1996 & 1 \\
\hline 1995 & 1 \\
\hline 1995 & 1 \\
\hline 1994 & 1 \\
\hline 1994 & 1 \\
\hline 1995 & 1 \\
\hline 1995 & 3 \\
\hline 1994 & 1 \\
\hline 1995 & 1 \\
\hline 1995 & 1 \\
\hline 1995 & 1 \\
\hline 1993 & 1 \\
\hline 1993 & 2 \\
\hline 1994 & 1 \\
\hline & \\
\hline & 1 \\
\hline
\end{tabular}




\begin{tabular}{|c|c|c|c|c|}
\hline 257 & FAO & Introduction to tropical Fish Stock Assessment & 1992 & 1 \\
\hline 258 & $\mathrm{FAO}$ & $\begin{array}{l}\text { A Guide to the Literature on Traditional Community-Based Fishery Management in the Asia- } \\
\text { Pacific Tropics }\end{array}$ & 1994 & 1 \\
\hline 259 & FAO & European Inland Fisheries Advisory Commission & 1996 & 1 \\
\hline 260 & $\mathrm{FAO}$ & $\begin{array}{l}\text { Regional Consultation on Institutional Credit for Sustainable Fish Marketing Capture and } \\
\text { Management in Asian and the Pacific }\end{array}$ & 1996 & 1 \\
\hline 261 & FAO & $\begin{array}{l}\text { FAO / Japan Expert Consultation on the Development of Community Based Coastal Fishery } \\
\text { Management Systems for Asia and the Pacific }\end{array}$ & 1993 & 3 \\
\hline 262 & FAO & Twentieth Session of the Committee on Fisheries & 1993 & 1 \\
\hline 263 & FAO & The Working Party on Fisheries Economics and Statistics & 1992 & 1 \\
\hline 265 & FAO & Sub-Committee for the Development and Management of the Fisheries of Lake Victoria & 1992 & 3 \\
\hline 266 & FAO & Fifth FAO Expert Consultation on Fish Technology in Africa & 1992 & 2 \\
\hline 267 & FAO & Fifteenth Session on the Coordinating Working Party on Atlantic Fishery Statistics & 1992 & 1 \\
\hline 268 & FAO & Sub-Committee on Fish Trade & 1993 & 1 \\
\hline 269 & FAO & Indian Ocean Fishery Commission & 1993 & 1 \\
\hline 270 & FAO & Fisheries and Research For Tunas and Tuna-Like Species in the Western Central Atlantic & 1996 & 1 \\
\hline 271 & FAO & A Strategic Reassessment of Fish Farming Potential in Africa & 1998 & 1 \\
\hline 272 & FAO & Fishery Intensification in Small Water Bodies & 1993 & 1 \\
\hline 273 & FAO & Simple Economics and Bookkeeping for Fish Formers & 1992 & 4 \\
\hline 274 & FAO & Guide to Fisheries Sector Studies & 1994 & 1 \\
\hline 276 & $\mathrm{FAO}$ & Inland fisheries of Europe & 1993 & 1 \\
\hline 277 & FAO & Marketing and consumption of Fish in Eastern and Southern Africa & 1993 & 1 \\
\hline 278 & FAO & Western Central Atlantic Fishery Commission & 1995 & 1 \\
\hline 279 & FAO & $\begin{array}{l}\text { Technical Consultation on the Precautionary Approach to Capture Fisheries (Including Species } \\
\text { Introductions }\end{array}$ & 1995 & 1 \\
\hline 280 & FAO & Indian Ocean Fishery Commission & 1995 & 1 \\
\hline 281 & FAO & General Fisheries Council for the Mediterranean & 1996 & 1 \\
\hline 282 & FAO & Western Central Atlantic Fishery Commission & 1996 & 1 \\
\hline 283 & FAO & Fishery Committee for the Eastern Central Atlantic & 1996 & 1 \\
\hline 284 & FAO & Indian Ocean Fishery Commission & 1996 & 1 \\
\hline 285 & FAO & Western Central Atlantic Fishery Commission & 1995 & 1 \\
\hline 286 & FAO & Coastal State Requirements for Foreign Fishing & 1993 & 2 \\
\hline 287 & FAO & General Fisheries Council for the Mediterranean & 1993 & 1 \\
\hline 288 & FAO & Committee on Fisheries & 1993 & 2 \\
\hline 289 & FAO & Directory of Educational and Training Opportunities in Fisheries and Aquaculture & 1993 & 2 \\
\hline 290 & FAO & Interactions of Pacific Tuna Fisheries & 1994 & 2 \\
\hline 291 & FAO & Review of the State of World Marine Fishery Resources & 1994 & 1 \\
\hline 292 & FAO & GENERAL FISHERIES COUNCIL FOR THE MEDITERRANEAN & 1997 & 1 \\
\hline 293 & FAO & ADVISORY COMMITTEE ON FISHERIES RESEARCH & 1997 & 1 \\
\hline 294 & FAO & $\begin{array}{l}\text { Workshop on Financing value-added Production and Marketing of Fishery Products in Asia and } \\
\text { the Pacific }\end{array}$ & 1997 & 1 \\
\hline
\end{tabular}




\section{Forestry}

\begin{tabular}{|c|c|}
\hline 295 & FAO \\
\hline 296 & $\overline{F A O}$ \\
\hline 297 & FAO \\
\hline 298 & $\overline{F A O}$ \\
\hline 299 & FAO \\
\hline 300 & FAO \\
\hline 301 & FAO \\
\hline 302 & FAO \\
\hline 303 & FAO et al \\
\hline 304 & FAO \\
\hline 305 & FAO \\
\hline 306 & FAO / SAREE \\
\hline 307 & FAO \\
\hline 308 & FAO \\
\hline 309 & FAO \\
\hline 310 & FAO \\
\hline 311 & FAO \\
\hline 312 & FAO \\
\hline 313 & FAO \\
\hline 314 & FAO \\
\hline 315 & FAO \\
\hline 316 & FAO \\
\hline 317 & FAO \\
\hline 318 & FAO \\
\hline 319 & FAO \\
\hline 320 & $\mathrm{FAO}$ \\
\hline .321 & FAO \\
\hline 322 & FAO \\
\hline 323 & FAO \\
\hline 324 & $\mathrm{FAO}$ \\
\hline 325 & $\mathrm{FAO}$ \\
\hline 326 & FAO \\
\hline 327 & FAO \\
\hline 328 & $\mathrm{FAO}$ \\
\hline 329 & $\overline{F A O}$ \\
\hline 330 & FAO / SIDA \\
\hline
\end{tabular}

Research Management in Forestry

Forest Products

Forest Products

Fabulous Forest Factories

Forests, Trees and People

LA FAO ET LA FORESTERIE

Research Management in Forestry

Readings in Sustainable forest Management

Assessing Forestry Project in Pacts

Mangrove Forest Management Guidelines

Management and Conservation of Closed Forestry in Tropical America

Mixed and Pure Forest Plantations in the Tropics and Subtropics

Securite Des Our Riers Forestiers

Forestry Policies in the Near East Region

Forest Products Prices

Forest Resources Assessment 1990

Forest Resources Assessment 1990

National Forestry Action Programs Update

Forestry Education

Forestry Department

Biotechnology in Forest tree improvement

Marketing Information Systems for-Timber Forest Products

Forest Genetic Resources

Decline and Dieback of Trees and Forests

Guide De Manipulation Des Semences Forestieres

Forestry Polices in the Near East Region

Tropical Forests Action Program Update

Produits Forestiers Non Ligneux

Potential of Urban Forestry in Developing Countries

Forest Genetic Resources

Integrated Small-Scale Forest Harvesting and Wool Processing Operation

Reduction of Wool Waste by Small-Scale Log Production and Conversion in Tropical High Forest Forest Harvesting Bulletin

Forest Harvesting Bulletin

Forestry For Development

Restoring the Balance Women and Forest Resources

\begin{tabular}{|l|c|}
\hline 1992 & 1 \\
\hline 1991 & 13 \\
\hline 1993 & 1 \\
\hline$?$ & 8 \\
\hline$?$ & 1 \\
\hline$?$ & 12 \\
\hline 1992 & 2 \\
\hline 1994 & 1 \\
\hline 1993 & 2 \\
\hline 1994 & 3 \\
\hline 1993 & 1 \\
\hline 1992 & 3 \\
\hline 1993 & 3 \\
\hline 1993 & 1 \\
\hline 1995 & 1 \\
\hline 1993 & 1 \\
\hline 1995 & 1 \\
\hline 1995 & 4 \\
\hline 1994 & 1 \\
\hline 1994 & 1 \\
\hline 1994 & 1 \\
\hline 1995 & 1 \\
\hline 1993 & 1 \\
\hline 1994 & 1 \\
\hline 1992 & 1 \\
\hline 1993 & 1 \\
\hline 1993 & 1 \\
\hline 1992 & 1 \\
\hline$?$ & 1 \\
\hline 1995 & 1 \\
\hline 1990 & 1 \\
\hline & \\
\hline 1992 & 1 \\
\hline 1995 & 2 \\
\hline 1996 & 1 \\
\hline$?$ & 2 \\
\hline$?$ & 1 \\
\hline & \\
\hline
\end{tabular}




\begin{tabular}{|c|c|}
\hline 331 & FAO \\
\hline 332 & FAO \\
\hline 333 & FAO et al \\
\hline 334 & FAO \\
\hline 335 & SARD \\
\hline 336 & FAO \\
\hline 337 & FAO et al \\
\hline 338 & FAO \\
\hline 339 & FAO \\
\hline 340 & FAO \\
\hline 341 & FAO \\
\hline 342 & FAO \\
\hline 343 & $\mathrm{FAO}$ \\
\hline
\end{tabular}

Peasant Participation in Community Reforestation

Forestry Statistics Today for Tomorrow

Valuing Forests Context Issues and Guidelines

Tropical Forest Action Program Stocking

The Road From RIO: Moving forward in Forestry

State Of The Worlds Forest

Manual On Acute Forest Damage

Forest Resources Assessment 1990

Report of the International Expert Consultation on Non-Wood Forest Products

Mon-Wood forest Products for Rural Income and Sustainable Forestry

Tropical Forest Action Program Stocktaking

An Annotated Bibliography on Urban Forestry in Developing Countries

Forestry Policies of Selected Countries in Asia and the Pacific

\section{Reports}

\begin{tabular}{|l|l|}
\hline 344 & FAO \\
\hline 345 & FAO \\
\hline 346 & UNITED NATIONS STAFF UNION \\
\hline 347 & PRB \\
\hline 348 & ANCB \\
\hline 349 & Shuhada Organization \\
\hline 350 & UNDP et al \\
\hline 351 & IFAD \\
\hline 352 & FAO \\
\hline 353 & The Voice of the Staff Union \\
\hline 354 & UNOPS / UNDP \\
\hline 355 & UNOPS \\
\hline 356 & UNOPS \\
\hline 357 & UNOPS \\
\hline 358 & UNOPS / UNDP \\
\hline 359 & UNFPA \\
\hline 360 & NPO / RRAA \\
\hline 361 & UNOCHA \\
\hline 362 & UNOPS / UNDP . \\
\hline 363 & FAO \\
\hline 364 & ANTHONY RALPH FITZH ERBERT \\
\hline 365 & ANTHONY RALPH FITZH ERBERT \\
\hline 366 & ANTHONY RALPH FITZH ERBERT \\
\hline 367 & ANTHONY RALPH FITZH ERBERT \\
\hline 368 & PRB \\
\hline
\end{tabular}

Material for Briefing Field Staff on Their Reporting Obligations

Program Implementation Report

UN Staff Report

Annual Report of 1995

Afghan NGO's Coordination Bureau Brief Activities Report 1991-96

Activities and Status Report 1996

Quarterly Operational Report

Seventeenth Session Report

Program Evaluation Report 1992 - 93

UN Staff Report

Monthly Progress Report

Sub-Projects By District Report

Sub-Projects By Sector Report

Sub-Projects By Region Report

Progress Report

Annual Report 1996

Annual Report 1996

1996 Consolidated Annual Report on Humanitarian Assistance to Afghanistan

Monthly Progress Report

Synthesis Report of Contributions from FAO Representatives on Special Theme: TCDC/ECDC

Second Draft Project Terminal Report

Draft Project Terminal Report

Second Draft Project Terminal Report

Second Draft Project Terminal Report

Annual Report 1996

\begin{tabular}{|l|l}
\hline 1994 & 2 \\
\hline Mar-93 & 1 \\
\hline Dec-96 & 1 \\
\hline 1995 & 1 \\
\hline$?$ & 1 \\
\hline 1996 & 1 \\
\hline Mar-97 & 1 \\
\hline 1994 & 2 \\
\hline 1993 & 4 \\
\hline 1998 & 1 \\
\hline Apr-98 & 1 \\
\hline 1998 & 1 \\
\hline 1998 & 1 \\
\hline 1998 & 1 \\
\hline 1997 & 1 \\
\hline 1996 & 1 \\
\hline 1996 & 1 \\
\hline 1996 & 1 \\
\hline May-98 & 1 \\
\hline 1992 & 1 \\
\hline 1995 & 1 \\
\hline 1994 & 1 \\
\hline 1995 & 1 \\
\hline 1995 & 4 \\
\hline 1996 & 1 \\
\hline
\end{tabular}


Training Materials

\begin{tabular}{|c|c|c|c|c|}
\hline 402 & Helen A. Strow & Educational Campaigns & May-74 & 1 \\
\hline 403 & Sue Murry & FARM AND HOME VISITS & May-74 & 1 \\
\hline 404 & Helen A. Strow & Helping Hands & May-74 & 1 \\
\hline 405 & FAO / UNDP & People's Participation Program in Ghana & 1995 & 1 \\
\hline 406 & FAO / UNDP & The Development of Independent Cooperatives in Zambia & 1994 & 1 \\
\hline 407 & FAO / UNDP & People's Participation in Rural Development in the Philippines & 1994 & $\overline{1}$ \\
\hline 408 & FAO / UNDP & FAO Collaboration With Asian NGO's for Participatory Rural Development & 1994 & 1 \\
\hline 409 & FAO / UNDP & Small Farmer Development Program in Thailand & 1994 & 1 \\
\hline 410 & FAO / UNDP & People's Participation Program in Pujehum, Sierra Leone & 1994 & 1 \\
\hline 411 & FAO & Experiences From the FAO People's Participation Program in Sri Lanka & 1994 & 1 \\
\hline 412 & Joseph F. Donnermeyer & Rural Sociological Society & 1984 & 1 \\
\hline 413 & University of Kentukey, Lexington, Kentucky & Rural Sociology & 1985 & 5 \\
\hline 414 & $\begin{array}{l}\text { Louisiana state University Baton Rouge, } \\
\text { Louisiana }\end{array}$ & Rural Sociology & 1986 & 1 \\
\hline 415 & Rural Sociological Society & The Rural Sociologist & 1986 & 1 \\
\hline 416 & Rural Sociological Society & The Rural Sociologist & 1987 & 9 \\
\hline 417 & RONALD M.BERNDT & Anthropological Forum & 1968 & 1 \\
\hline 418 & RONALD M.BERNDT & Anthropological Forum & 1970 & 1 \\
\hline 419 & RONALD M.BERNDT & Anthropological Forum & 1967 & 1 \\
\hline 420 & FAO & La Comunication Para El Desarrollo rural & $?$ & 1 \\
\hline 421 & The Uyole Agricultural Center & Training Institute & 1989 & 1 \\
\hline 422 & FAO & FAO Publications & 1995 & 2 \\
\hline 423 & Karl Mannheim & Sentiments And Activities & 1962 & 1 \\
\hline 424 & The Department of information of Sri Lanka & Export Production Villages & $?$ & 1 \\
\hline 425 & Penguin Education & Reconstructing Social Psychology & 1976 & 1 \\
\hline 426 & $\begin{array}{l}\text { Department of Anthropology University of } \\
\text { Sydney }\end{array}$ & Social Change & Sep-75 & 1 \\
\hline 427 & GEROLD ZALTMAN et al & Greeting Social Change & Dec-71 & 1 \\
\hline 428 & FAO & FAO Documentation & 1993 & 3 \\
\hline 429 & FAO & FAO Documentation & 1994 & 4 \\
\hline 430 & FAO & FAO Documentation & & 7 \\
\hline 431 & $\begin{array}{l}\text { New Guinea Research Unit Australian } \\
\text { National University }\end{array}$ & New Guinea Research Unit Bulletin & 1966 & 1 \\
\hline 432 & $\begin{array}{l}\text { New Guinea Research Unit Australian } \\
\text { National University }\end{array}$ & New Guinea Research Bulletin & Feb-69 & 1 \\
\hline 433 & FAO & Communication A Key to & 1991 & 1 \\
\hline 434 & FAO & Learning from Experience & 1995 & 2 \\
\hline
\end{tabular}




\begin{tabular}{|c|c|c|c|c|}
\hline 435 & FAO & Science and Technology in the World of FAO & $?$ & 2 \\
\hline 436 & UNDP & Placing Women in the center of the Analysis & Nov-93 & 2 \\
\hline 437 & OCDE, CAD & Le Developpement Participat if et La Bonnegestion des Affaires Publiques & 1995 & 2 \\
\hline 438 & FAO et al & Guideline For Cost Effectiveness Analysis of Vector control & 1993 & 3 \\
\hline 439 & FAO & List of Selected Articles (LOSA) & 1995 & 5 \\
\hline 441 & $\begin{array}{l}\text { Cox And Wyman LTD, London Reading and } \\
\text { Fakenhem Set in monotype Times }\end{array}$ & Human Groups & May-58 & 1 \\
\hline 442 & Roland L.Warren & Furth Love and Social change & May-70 & 1 \\
\hline 443 & $\begin{array}{l}\text { Ya Le University Press New Haven and } \\
\text { London }\end{array}$ & The Londy Crowd & Nov-60 & 1 \\
\hline 444 & $\begin{array}{l}\text { The University of New England Armidale, } \\
\text { WSW Australia }\end{array}$ & International Development Training Program & Aug-96 & 1 \\
\hline 445 & FAO & The Asia And Pacific Seed Association (APSA) & $?$ & 1 \\
\hline 446 & R. HARRE & The Explanation of Social Behavior & 1976 & 1 \\
\hline 447 & GEORGE M.BEAL et al & Sociological Perspectives of Domestic Development & 1971 & 1 \\
\hline 448 & $\begin{array}{l}\text { Pakistan Agricultural Research Council } \\
\text { Islamabad }\end{array}$ & Research Digest & 1994 & 1 \\
\hline 449 & FAO & Gian Tommaso Scarascia Mugnozza & Oct-95 & 1 \\
\hline 450 & UNIDD & Guide to training Opportunities for Industrial Development & 1995 & 1 \\
\hline 451 & FAO & FAO Land Tenare Studies 1 & 1995 & 1 \\
\hline 453 & CAD & $\begin{array}{l}\text { L'Aide des Donneursen Faveur Du Developpement des Capacities Dans Le domaine De } \\
\text { l'environnement }\end{array}$ & 1995 & 1 \\
\hline 454 & FAO & Trade Patterns, Cooperation and Growth & 1995 & 1 \\
\hline 455 & JOHN.S SVENDSEN & Sources of Goods And Services Development Assistance & 1995 & 1 \\
\hline 456 & UNDP & Gender Poverty and Sustainable Development & 1995 & 1 \\
\hline 457 & UNDP & Potential Sources of Goods and Services the Netherlands & May-95 & 1 \\
\hline 458 & UNDP & Potential Sources of Goods and Services the Finland & Jun-95 & 1 \\
\hline 459 & FAO & Names of Countries & Apr-95 & 1 \\
\hline 460 & FAO & Names of Countries & Oct-95 & 1 \\
\hline 461 & FAO & Inventory Credit & 1995 & 1 \\
\hline 462 & FAO & Safeguarding Deposits & 1995 & 1 \\
\hline 463 & FAO / UNDP & A Manager's Guide to the Use of Rapid Rural Appraisal & 1995 & 1 \\
\hline 464 & FAO & Development Support Communication & 1993 & 1 \\
\hline 465 & FAO & Guiding Principles for People's Participation Projects & 1983 & 1 \\
\hline 466 & FAO & Tillage Systems in the Tropics & 1995 & 1 \\
\hline 467 & FAO & Field Projects & 1994 & 1 \\
\hline 468 & FAO & Rural Development & 1996 & 2 \\
\hline 469 & FAO & Cherish The Earth & 1994 & 1 \\
\hline 470 & FAO & Projected Pulp And Paper Mills in the world 1994-99 & 1995 & 1 \\
\hline 471 & FAO & A Fairer Future For Women & May-95 & 1 \\
\hline
\end{tabular}




\begin{tabular}{|c|c|c|c|c|}
\hline 472 & FAO & Applying D.Sc. Methodologies to Population Issues & 1994 & 2 \\
\hline 473 & FAO & Guidelines on Communication for Rural Development & $?$ & 1 \\
\hline 474 & $\begin{array}{l}\text { University of the South Pacific Rural } \\
\text { Development Center }\end{array}$ & Small Business and Law & 1983 & 1 \\
\hline 475 & $\begin{array}{l}\text { University of the South Pacific Rural } \\
\text { Development Center }\end{array}$ & Taxation and the small Business & 1983 & 1 \\
\hline 476 & $\begin{array}{l}\text { University of the South Pacific Rural } \\
\text { Development Center }\end{array}$ & Insurance for the Small Project & 1983 & 1 \\
\hline 477 & $\begin{array}{l}\text { University of the South Pacific Rural } \\
\text { Development Center }\end{array}$ & Staff And Personnel Matters & 1983 & 1 \\
\hline 478 & $\begin{array}{l}\text { University of the South Pacific Rural } \\
\text { Development Center }\end{array}$ & Marketing & 1983 & $\dot{1}_{1}$ \\
\hline 479 & $\begin{array}{l}\text { University of the South Pacific Rural } \\
\text { Development Center }\end{array}$ & Importing and Exporting & 1983 & 1 \\
\hline 480 & $\begin{array}{l}\text { University of the South Pacific Rural } \\
\text { Development Center }\end{array}$ & Credit Policy for the Small Business & 1983 & 1 \\
\hline 481 & $\begin{array}{l}\text { University of the South Pacific Rural } \\
\text { Development Center }\end{array}$ & Sources of Help for Small Projects & 1983 & 1 \\
\hline 483 & The American Home Economics Association & Village Visuals & $?$ & 1 \\
\hline 484 & FAO & Dryland Development and Combating desertification & 1995 & 1 \\
\hline 485 & $\mathrm{FAO}$ & World Review of Highly Migratory Species and Straddling Stocks & 1994 & 1 \\
\hline 486 & WHO & Teaching Skills Development Manual & $?$ & 1 \\
\hline 487 & $\mathrm{FAO}$ & Teaching Advisory Support for the Corum-Cankiri Rural Development Project & 1984 & 1 \\
\hline 488 & $\begin{array}{l}\text { Department of Human Geography Research } \\
\text { School of Pacific Studies the Australian } \\
\text { National University Canberra }\end{array}$ & Makit Raun Pilot Project Feasibility Study & 1974 & 1 \\
\hline 489 & U.S. Department of Agriculture & Teaching And Applying Educational Principles in EFNEP & $?$ & 1 \\
\hline 490 & FAO & Training manual on Puple's Participation & 1984 & 1 \\
\hline 491 & $\begin{array}{l}\text { The Voluntary Fund For the United Nations } \\
\text { Decade for Women }\end{array}$ & A Guide to Community Revolving Loan Furless & $?$ & 1 \\
\hline 492 & FAO & Intensiticacion De La Pesca En Los Pequenos Cuerpos De Aqua En America Latina Y El Caribe & 1994 & 1 \\
\hline 493 & FAO & FAO's Investment Center & $?$ & 2 \\
\hline 494 & FAO & World Apparel Fivre Lon Sumption Survey & 1994 & 1 \\
\hline 495 & FAO & Land Reform & & 1 \\
\hline 496 & FAO & List of Selected Articles (LOSA) & 1995 & 1 \\
\hline
\end{tabular}




\begin{tabular}{|c|c|c|c|c|}
\hline 497 & UNESCO & Science and Education & $?$ & 1 \\
\hline 498 & $\begin{array}{l}\text { The Royal Veterinary College University of } \\
\text { London }\end{array}$ & Post Graduate Prospectus & $?$ & 1 \\
\hline 499 & ESCAP / FAO / UNIDO & Supply, Marketing Distribution And use of Fertilizer in the Islamic Republic of Iran & 1994 & 1 \\
\hline 500 & FAO & Director General's Bulletin & 1995 & 1 \\
\hline 501 & FAO & Practical Aspects of Stocking Small Water Bodies & 1994 & $\overline{1}$ \\
\hline 502 & FAO & Administrative Circular & Feb-95 & 1 \\
\hline 503 & FAO & Information Note & May-95 & 1 \\
\hline 504 & FAO et al & Land Degradation in South Asia & 1994 & 1 \\
\hline 505 & UNDP & Conserving Indigenous Knowledge & Sep-94 & 1 \\
\hline 506 & FAO & Rural Financial Markets Research in Progress No. 6 & Jul-95 & $\overline{1}$ \\
\hline 507 & FAO / UNDP & Communication & 1994 & 1 \\
\hline 508 & $\begin{array}{l}\text { Technical Cooperation Among Developing } \\
\text { Countries }\end{array}$ & Cooperation South & May-95 & 1 \\
\hline 509 & FAO & Maintenance and Operation of Bulgarian Stores & 1994 & 1 \\
\hline 510 & UNDP & Poverty Eradication in the Asia Pacific Region & Oct-97 & 1 \\
\hline 511 & FAO & Land Reform & 1994 & 1 \\
\hline 512 & UNDP & Power Generators & May-94 & 1 \\
\hline 513 & FAO & Commodity Review and Outlook & & 1 \\
\hline 514 & FAO & FAO's emergency activities & 1997 & 1 \\
\hline 515 & Ronal M. Berndt & Anthropological forum & 1971 & 1 \\
\hline 516 & $\mathrm{FAO}$ & Collection FAO: Development Statistique & 1992 & 1 \\
\hline 517 & FAO & Conduite de Petites & 1992 & 1 \\
\hline 518 & FAO & Les Banques au Survice De L'environnement & 1993 & 1 \\
\hline 519 & FAO & Guide Des Approches Possibles & 1993 & 1 \\
\hline 520 & FAO & Names of Countries & Dec-93 & 1 \\
\hline 521 & FAO & Design of Poverty Allecviation Strategy in Rural Areas & 1993 & 1 \\
\hline 522 & FAO & Land - use Planning & 1993 & 2 \\
\hline 523 & FAO & Torrent Control and Streambed Stabilization & 1993 & 2 \\
\hline 524 & FAO & Abbreviations Sigils & 1994 & 1 \\
\hline 525 & FAO & Administrative and Financial Terms & 1994 & 2 \\
\hline 526 & FAO & Policies for Sustainable Development & 1994 & 2 \\
\hline 527 & FAO & Management of Insect Pests & Oct-92 & 2 \\
\hline 528 & FAO & The Role of Financial Services in Rural Development & Jan-93 & 1 \\
\hline 529 & FAO & Implementing the ICN Plan of Action & Feb-93 & 1 \\
\hline 530 & FAO & Projected Pulp and Paper mills in the World $1993-98$ & 1994 & 1 \\
\hline 531 & FAO & Training For Decentralized Planning & 1987 & 1 \\
\hline 532 & FAO & Guidelines on Social Analysis & 1993 & 1 \\
\hline $5 \overline{33}$ & FAO & Rural Finacce In FAO & Jun-94 & 1 \\
\hline 534 & FAO & Director of FAO Statutory Bodies And Panels of Experts & Mar-94 & 1 \\
\hline 535 & $\mathrm{FAO}$ & Commodity Review and Outlook $1993-94$ & 1994 & 7 \\
\hline 536 & $\overline{F A O}$ & Country Tables & 1992 & 2 \\
\hline 537 & FAO & Trade & 1991 & 14 \\
\hline
\end{tabular}




\begin{tabular}{|c|c|c|c|c|}
\hline 538 & FAO & Trade & 1992 & 16 \\
\hline 539 & FAO & FAO Quarterly Bulletin of Statistics & 1992 & 1 \\
\hline 540 & FAO & Fertilizer & 1993 & 1 \\
\hline 541 & FAO & Trade & 1993 & 1 \\
\hline 542 & FAO & FAO Quarterly Bulletin of Statistics & 1993 & 5 \\
\hline 543 & FAO & Production & 1994 & 1 \\
\hline 544 & FAO & Fertilizer & 1994 & 1 \\
\hline 545 & FAO & FAO Quarterly Bulletin of Statistics & 1994 & 1 \\
\hline 546 & JUN / Afghanistan & Consolidated Appeal For Afghanistan & 1998 & 19 \\
\hline 547 & FAO & Reorienting the Cooperative Structure in Selected Eastern European Countries & 1994 & 8 \\
\hline 548 & FAO & Trainers Guide & 1993 & 2 \\
\hline 549 & Consolidated Appeal For Afghanistan & Mid Term Review' & Jul-97 & 7 \\
\hline 550 & FAO & Technical Background Documents 1 - 5 & 1996 & 3 \\
\hline 551 & FAO & Names of Countries & 1992 & 1 \\
\hline 552 & FAO & Projected Pulp and Paper mills in the World $1992-97$ & 1993 & 2 \\
\hline 553 & UNDP & Afghanistan Rehabilitation Steering Committee & Nov-95 & 1 \\
\hline 554 & UNHCR & CIS Conference & May-96 & 1 \\
\hline 555 & UNDP & Afghanistan ....... From Relief to Self - Reliance & $?$ & 6 \\
\hline 556 & UNITED NATIONS & Program Steering Committee & Jul-96 & 1 \\
\hline 557 & UNDP & Action Plan for Immediate Rehabilitation & Oct-93 & 3 \\
\hline 558 & FAO & Pamir Reconstruction Bureau Veterinary Project & 1995 & 1 \\
\hline 559 & FAO & Study on the Nutritional Aspect of Badakhshan Province, Afghanistan & May-96 & 1 \\
\hline 560 & UNITED NATIONS & Summary of Security Procedures in Afghanistan & 1995 & 1 \\
\hline 561 & UUNITED NATIONS & Consolidated Appeal for Assistance & 1997 & 1 \\
\hline 562 & WHO & Guidelines for Dog Rabies Control & Mar-84 & 1 \\
\hline 563 & PC Direct & The Buyer's Guide to Products and Prices & Aug-97 & 1 \\
\hline 564 & FAO & Computer Application to the Cadaster and Land Registration in the Near East & 1993 & 2 \\
\hline 565 & XEROX & Tab Works & Sep-93 & 1 \\
\hline 566 & Compaq & Beyond Setup & ? & 1 \\
\hline 567 & Compaq & Beyond Setup & 1994 & 1 \\
\hline 568 & UNDP & Energy After RIO & 1997 & 1 \\
\hline 569 & UNDP & Field Motocycles & $\operatorname{Jan}-95$ & 1 \\
\hline 570 & UNDP & Personal Computers & Aug-94 & 1 \\
\hline 571 & UNDP & Field Motor Vehicles & Oct-94 & 1 \\
\hline 572 & UNDP & Office Equipment & Aug-94 & 1 \\
\hline 573 & FAO & Country Tables & 1994 & 1 \\
\hline 574 & FAO & Country Tables & 1995 & 1 \\
\hline 575 & GTSI & GSA Schedule B/C & 1995 & 1 \\
\hline 576 & FAO & The dynamics of Agrian Structures in Europe & 1988 & 1 \\
\hline 577 & Richard Kwanoriental Suppliers Ltd. & 25th Anniversary & 1994 & 1 \\
\hline 578 & UNDP / APSO & Office Equipment & Sep-95 & 1 \\
\hline 579 & FAO & Bioenergy for development & 1994 & 1 \\
\hline
\end{tabular}




\begin{tabular}{|c|c|c|c|c|}
\hline 580 & FAO & Rural Poverty alleviation & 1993 & 2 \\
\hline 5.81 & FAO & Torrent Control and Streambed Stabilization & 1993 & 2 \\
\hline 582 & FAO & Design of Poverty alleviation Strategy in Rural Areas & 1993 & 2 \\
\hline 583 & FAO & Textes Fondamentaux & 1992 & 3 \\
\hline 584 & FAO & Basic Texts & 1992 & 5 \\
\hline 586 & UNDP / UNFPA & Population & 1996 & 1 \\
\hline 587 & UNICEF & The State of the world's children & 1997 & 1 \\
\hline 588 & UNICEF & First call for Children & 1990 & 1 \\
\hline 589 & UNOCHA & Aina & Sum 1998 & 3 \\
\hline 590 & UNOCHA & Aina & 1998 & 4 \\
\hline 591 & FAO & Youth Works & Jul-94 & 1 \\
\hline 592 & FAO & The FAO Program in Afghanistan & 1995 & 1 \\
\hline 593 & FAO & The Occurrence of Resistance to Pesticides in Arthropods & 1991 & 1 \\
\hline 594 & ODA & Our Client the Small Holder & 1992 & 1 \\
\hline 595 & ICARDA & Medium - Term Plan 1994 - 98 & 1998 & 1 \\
\hline 596 & FAO & The Yak & 1995 & 1 \\
\hline 597 & FAO & Manual on Simple Methods of Meat Preservation & 1990 & 1 \\
\hline 598 & FAO & Manual De Formation Partique Pour La Transplantation embryonnaire chez La brebis et La chevre & 1993 & 1 \\
\hline 599 & FAO & Manual de Formation Pour l'insemination artificielle chez les ovins et les caprins & 1993 & 1 \\
\hline
\end{tabular}

\section{Livestock}

\begin{tabular}{|c|c|}
\hline 601 & FAO \\
\hline 602 & UNDP \\
\hline 603 & UNIFM \\
\hline .604 & FAO \\
\hline 605 & FAO \\
\hline 606 & FAO / UNEP \\
\hline 607 & FAO / UNEP \\
\hline 608 & FAO \\
\hline 609 & FAO \\
\hline 610 & $\mathrm{FAO}$ \\
\hline 611 & $\mathrm{FAO} / \mathrm{WHO}$ \\
\hline 612 & FAO \\
\hline 613 & $\mathrm{FAO} / \mathrm{WHO} / \mathrm{OIE}$ \\
\hline 614 & $\mathrm{FAO} / \mathrm{WHO} / \mathrm{OIE}$ \\
\hline
\end{tabular}

Physiology

Basic veterinary education for Rural Women of Afghanistan

Dairy Processing

In Situ Conservation of Livestock and Poultry

Veterinary education

Animal Genetic Resources information

Animal Genetic Resources information

Quality Control of Veterinary Vaccines in developing Countries

Farm Management Research for Small Farmer development

Use of Applicable Biotechnological methods for diagnosing haemoparasites

Codex Alimentarius

Body Moss Index

Animal Health Yearbook

Animal Health Yearbook

\begin{tabular}{|l|c|}
\hline 1993 & 1 \\
\hline Jan-96 & 1 \\
\hline 1994 & 15 \\
\hline 1992 & 1 \\
\hline 1995 & 1 \\
\hline 1993 & 1 \\
\hline 1994 & 1 \\
\hline 1993 & 1 \\
\hline 1993 & 2 \\
\hline 1994 & 1 \\
\hline 1993 & 4 \\
\hline 1994 & 1 \\
\hline 1994 & 1 \\
\hline 1993 & 1 \\
\hline
\end{tabular}




\begin{tabular}{|c|c|c|c|c|}
\hline 615 & FAO & World Statistical Compendium for Raw Hides and Skins, Leather and Leather foot Wear $1974-92$ & 1994 & 1 \\
\hline 616 & UNDP / OPS & 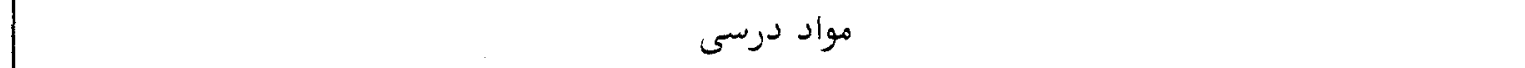 & 1995 & 2 \\
\hline 617 & FAO & A Systematic Approach to Tsetse and trypanosomiasis Control & 1994 & 1 \\
\hline 618 & FAO & What About the Wild Animals? & 1995 & 1 \\
\hline 619 & $\mathrm{FAO}$ & The Farming Systems Approach to Development and Appropriate technology Generation & 1995 & 1 \\
\hline 620 & FAO & Understanding Farmers Communication Networks & 1995 & 1 \\
\hline 621 & FAO & Domestication and Husbandry of the Paca (Agoutiraca) & 1995 & 1 \\
\hline 622 & $\mathrm{FAO}$ & World Animal Review & 1992 & 1 \\
\hline 623 & D.B. GIBBS & Communication Patterns Among Sheep Formers North Island Districts of Zealand & 1970 & 1 \\
\hline 624 & FAO & Sustainable Range Dependent Small Ruminant Production Systems & 1995 & 1 \\
\hline 625 & $\mathrm{FAO}$ & Agrindex & 1993 & $5 \cdot$ \\
\hline 626 & $\mathrm{FAO}$ & Agrindex & 1992 & 2 \\
\hline 627 & FAO & Agrindex & 1994 & 2 \\
\hline 628 & $\mathrm{FAO}$ & Elephants in Logging Operations in Sri Lanka & 1995 & 1 \\
\hline 629 & FAO & Animal Health and Livestock Production Program in Afghanistan & Sep-96 & 2 \\
\hline 630 & $\mathrm{FAO}$ & The Animal Health and Livestock Production Programme for Afghanistan & 1994 & 1 \\
\hline 631 & Ministry of Agricultural & National Agriculture and Livestock extension Policy and Implementation Guidelines & 1992 & 1 \\
\hline 632 & FAO & Livestock Production & Jul-96 & 2 \\
\hline 633 & FAO & Collecting Data on Livestock & 1992 & 1 \\
\hline 634 & FAO & Strategies for Sustainable Animal Agriculture in Developing Countries & 1993 & 2 \\
\hline 635 & CAB International & Animal Science & $?$ & 1 \\
\hline 636 & FAO & Edible by - Products of Slaughter Animals & 1996 & 1 \\
\hline 637 & $\mathrm{FAO}$ & World Animal Review & 1994 & 3 \\
\hline 638 & $\mathrm{FAO}$ & World Animal Review & 1995 & 3 \\
\hline 639 & $\mathrm{FAO}$ & World Animal Review & 1993 & 2 \\
\hline 640 & FAO & World Animal Review & 1992 & 4 \\
\hline 641 & NACA / FAO & Aquatic Animal Quarantine And Health Certification in Asia & 1997 & 1 \\
\hline 642 & & & & \\
\hline
\end{tabular}

\begin{tabular}{|l|l|}
\hline 643 & FAO \\
\hline 644 & FAO \\
\hline 645 & FAO \\
\hline 646 & TOYOTA \\
\hline 647 & FAO \\
\hline 648 & FAO \\
\hline 649 & FAO \\
\hline 650 & FAO \\
\hline 651 & FAO \\
\hline
\end{tabular}

Names of Countries

Names of Countries

Names of Countries

Owner's Manual

Council

Council

Medium - Term Plan 1994 - 99

Council

Conference

\begin{tabular}{|l|c|}
\hline 1993 & 3 \\
\hline 1991 & 1 \\
\hline 1992 & 1 \\
\hline 1997 & 3 \\
\hline 1993 & 20 \\
\hline 1994 & 5 \\
\hline 1993 & 4 \\
\hline 1991 & 1 \\
\hline 1991 & 3 \\
\hline
\end{tabular}




\begin{tabular}{|c|c|c|c|c|}
\hline 656 & FAO & EL-Pejerrey (Odonthestes bonariensis) Metodos de Cria y Cultivo Masivo & 1995 & 1 \\
\hline 657 & FAO & Lista De Acuicultores De America Latina y El Caribe & 1995 & 2 \\
\hline 658 & FAO & FAO Quarterly Bulletin of Statistics & 1993 & 11 \\
\hline 659 & FAO & Field Measurement of Soil Erosion and Run Off & 1993 & 1 \\
\hline 660 & FAO & Soil Tillage in Africa: Needs and Challenges & 1993 & 1: \\
\hline 661 & FAO & Risk Analysis in Dryland Farming Systems & 1992 & 1. \\
\hline 662 & $\mathrm{FAO}$ & Cropwat & 1992 & 1 \\
\hline 663 & $\mathrm{FAO}$ & Cereal Policies Review 1992 - 93 & 1993 & 1 \\
\hline 664 & $\mathrm{FAO}$ & Sampling Plans for Aflatoxin Analysis in Peanuts and Corn & 1993 & 1 \\
\hline 665 & FAO/IPGRI & Small Grain Temperate Cereals & 1995 & 1 \\
\hline 666 & $\begin{array}{l}\text { The New Guinea Research Unit, Australian } \\
\text { National University }\end{array}$ & New Guinea Research Unit Bulletin & Dec-65 & 1 \\
\hline 667 & $\begin{array}{l}\text { Department of Agriculture, University of } \\
\text { Queensland, Brisbane }\end{array}$ & Economic Success in the wool industry & 1977 & 1: \\
\hline 668 & FAO & هنظه الاشذيه والزراته فى هواجهـ تحديات التنديـ & 1993 & 1 \\
\hline 669 & National Institute of Community Development & Farmers and their Aspirations & 71 & 1 \\
\hline 670 & Problems of Regional Development & Integrated Rural Development & 79 & 1 \\
\hline 671 & UNDP & The Experience of Egypt & 95 & 1 \\
\hline 672 & UNDP & Afghanistan... from Relief to Self Reliance & $?$ & 1 \\
\hline 673 & UNDP /FAO & Suketar Watershed Management Project & $?$ & $1 !$ \\
\hline 674 & UNDP & The Experience of China & 1995 & 1 \\
\hline 675 & UNDP & The Experience of Elsalvador & 1995 & 1 \\
\hline 676 & UNDP & The Experience of Guinea & 1995 & 11 \\
\hline 677 & UNDP & The Experience of Malavi & 1995 & 11 \\
\hline 678 & UNDP & The Experience of Philippines & 1995 & 1 \\
\hline 679 & UNDP & The Experience of Pacific Island Countries & 1995 & 1 \\
\hline .680 & UNDP & The Experience of Sudan & 1995 & 1 \\
\hline 681 & UNDP & The Experience of Turkey & 1995 & 1 \\
\hline 682 & UNDP & The Experience of Ukraine & 1995 & 1 \\
\hline 683 & UNDP & The Experience of Pakistan & 1995 & 1 \\
\hline 684 & FAO & Maize & 1987 & 1 \\
\hline 685 & FAO IAGRIS / CARIS & Twentieth Anniversary Celebration Proceedings & 1994 & 1 \\
\hline 686 & $\mathrm{FAO}$ & Improved Rice Farming Systems & 1994 & $1 !$ \\
\hline 687 & Jan Hogbin and Peter Lawrence & Studies in New Guinea Land tenure & 1967 & $1 i$ \\
\hline 688 & FAO & Safeguarding Deposits & 1995 & 1 \\
\hline 689 & FAO & Ex Situ Storage of Seeds, Pollen and in Vitrocultures of Plant Species & 1993 & $\overline{11}$ \\
\hline 690 & Sylvia Brunold & $\begin{array}{l}\text { Investigation on Current yield potential on tax allotments on the Islands of Ha'aai and Vava'v, } \\
\text { Kingdom of Tonga South Pacific }\end{array}$ & 1983 & 1 \\
\hline
\end{tabular}




\section{General}

\begin{tabular}{|c|c|c|c|c|}
\hline 687 & FAO & The Impact of Development Strategies on the Rural Poor & 1988 & 1 \\
\hline 688 & FAO & $\begin{array}{l}\text { Guidelines on Socio-Economic Indicators for monitoring and evaluating Agrian Reform and Rural } \\
\text { Development }\end{array}$ & 1988 & 1 \\
\hline 689 & IFAO & $\begin{array}{l}\text { Status of Implementation of the International Code of Conduct on the Distribution and Use of } \\
\text { Pesticides in the Near East Region }\end{array}$ & 1992 & 1 \\
\hline 690 & United Nations Women's Association & Welcome to Pakistan & 1993 & 1 \\
\hline 691 & UNDCP & Information Letter & 1995 & 2 \\
\hline 692 & FAO & Technology of Hybrid Rice Production & 1995 & 1 \\
\hline$\overline{693}$ & FAO & How Development Projects Can Promote Sustainable and Viable Financial Services & 1995 & 1 \\
\hline 694 & FAO & A Faire Future for Rural Women & 1994 & 2 \\
\hline 695 & FAO & Eradicating the Screw Worm & 1992 & 1 \\
\hline 696 & FAO & Social and Economic Incentives for Small Holder Tree growing & $?$ & 1 \\
\hline 697 & FAO & Treaties Concerning the Non-Navigational Uses of International Water Courses & 1995 & 1 \\
\hline 698 & FAO & Rodent Pest Management in Eastern Africa & 1994 & 2 \\
\hline 699 & FAO & Date Plan Products & 1993 & 1 \\
\hline 700 & FAO & Debt-For-Nature Swaps to Promote Natural Resource Conservation & 1993 & 1 \\
\hline 701 & IAEA & Feedding Strategies for Improving Ruminant Productivity in Areas of Fluctuating Nutrient Supply & 1993 & 2 \\
\hline 702 & FAO & للجنه مصايدالاسعاى & 1993 & 1 \\
\hline 703 & FAO & Demond Forecasting for Fertilizer Marketing & 1994 & 2 \\
\hline 704 & FAO & CLIMWAT FOR CROPWAT & 1993 & 1 \\
\hline 705 & FAO & Pulp and Paper Capacities & 1992 & 1 \\
\hline 706 & FAO & Pulp and Paper Capacities & 1993 & 1 \\
\hline 707 & FAO & Pulp and Paper Capacities & 1994 & 2 \\
\hline
\end{tabular}

\section{Magazine / News / Journal}

\begin{tabular}{l|l|l|l|}
\hline 708 & CDAP & & \multicolumn{1}{|c|}{2} \\
\hline 709 & CARE & Jul-98 & \\
\hline 710 & UNDP & Program in - Touch & 1 \\
\hline 711 & NPO/RRAA & Poverty, Eradication and Community Empowerment & Aug-97 \\
\hline 712 & FAO & Academy for Human Resources and Organizational Development & 19 \\
\hline 713 & FAO & The Regional Office for the Near East in Action & $?$ \\
\hline
\end{tabular}




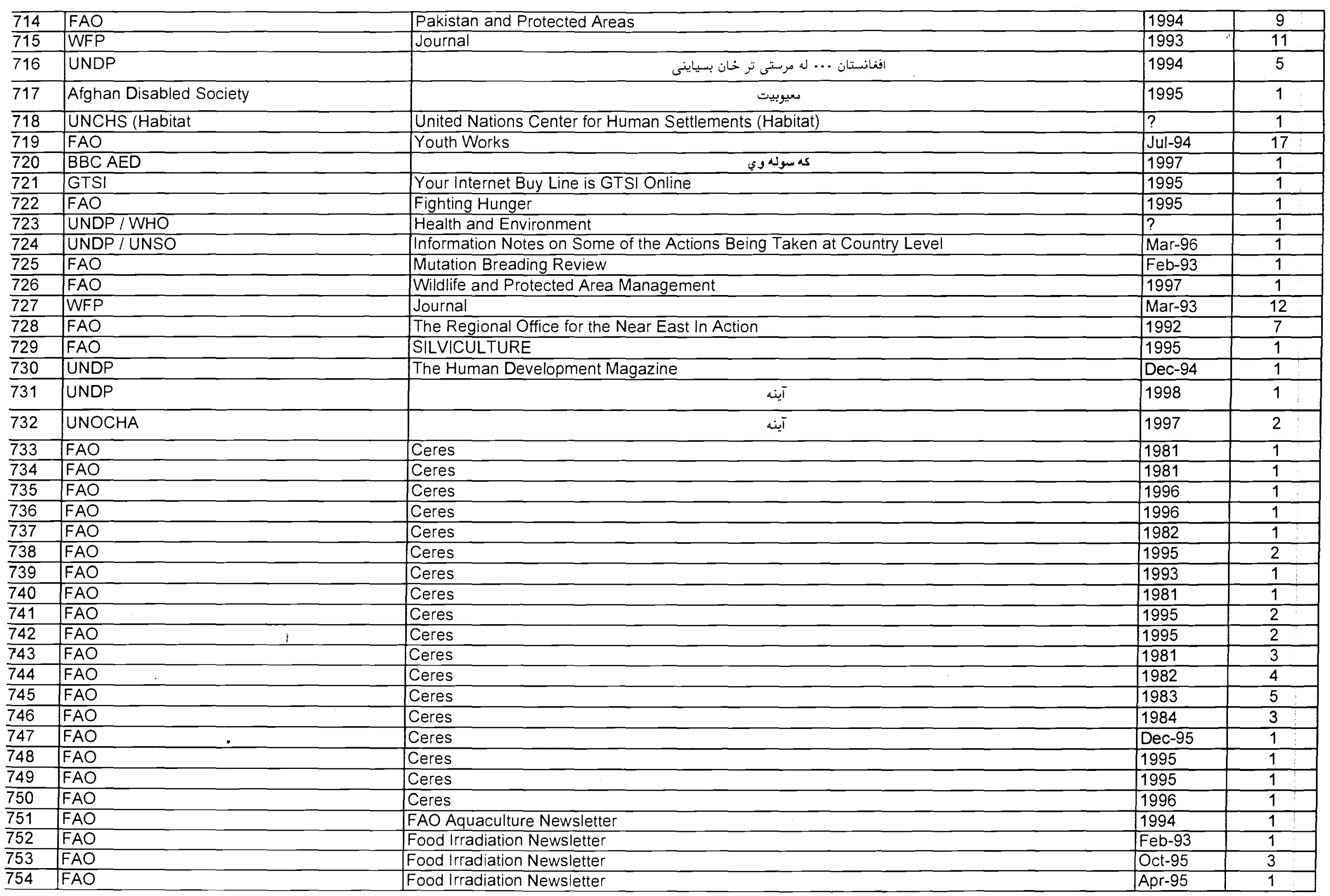




\begin{tabular}{|c|c|}
\hline 755 & FAO \\
\hline 756 & FICSA \\
\hline 757 & FICSA \\
\hline 758 & FAO \\
\hline 759 & FAO \\
\hline 760 & FAO \\
\hline 761 & UNDP \\
\hline 762 & FAO \\
\hline 763 & FAO \\
\hline 764 & FAO \\
\hline 765 & UNDP \\
\hline 766 & UNDP \\
\hline 767 & BBC AED \\
\hline 768 & FAO \\
\hline 769 & FAO \\
\hline 770 & FAO \\
\hline 771 & FAO \\
\hline 772 & FAO / WFP \\
\hline 773 & FAO \\
\hline 774 & FAO \\
\hline 775 & FAO \\
\hline 776 & SPACH \\
\hline 777 & FAO \\
\hline 778 & FAO \\
\hline 779 & FAO \\
\hline 780 & FAO \\
\hline 781 & ESCAP / FAO / UNIDO \\
\hline 782 & ESCAP / FAO / UNIDO \\
\hline 783 & ESCAP / FAO / UNIDO \\
\hline 784 & FAO \\
\hline 785 & FAO / UNESCO \\
\hline 786 & FAO / UNESCO \\
\hline 787 & FAO \\
\hline 788 & FAO \\
\hline 789 & FAO \\
\hline 790 & FAO \\
\hline 791 & FAO \\
\hline 792 & FAO \\
\hline 793 & FAO et al \\
\hline 794 & FAO \\
\hline 795 & ICIMOD \\
\hline 796 & FAO \\
\hline
\end{tabular}

Soils Newsletter

Newsletter

Bulletin

News Release

FAO Aquaculture Newsletter

AARINENA Newsletter

UNDP NewS

Animal Production and Health Newsletter

Animal Production and Health Newsletter

Animal Production and Health Newsletter

UNDP News

UNDP NEWS

Evaluation Newsletter

Newsletter (Pushto)

Newsletter

FAO Aquaculture Newsletter

Soils, Newsletter

FSA News

NEWSLETTER

NEWSLETTER

NEWSLETTER

Newsletter

Newsletter

Newsletter

Newsletter

Newsletter

Agrochemicals, News in Brief

Agrochemicals News in Brief

Agro chemicals, News in Brief

Agro chemicals, News in Brief

Marine Science Contents Tables

Marine Science Contents Tables

Wastewater Management for Irrigation

Considerations of Wastewater

Monitoring Wastewater Quality for Irregation

Wastewater As A Crop Nutient Source

استخدام الميام العادمه و علاقتها بطحه الانسان

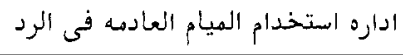

Poverty Eradication and Community Empoverment

Fighting Hunger

SEABUCKTHORN

Youth Works 


\begin{tabular}{|c|c|}
\hline 797 & $\mathrm{FAO}$ \\
\hline 798 & FAO \\
\hline 799 & FAO \\
\hline 800 & $\mathrm{FAO}$ \\
\hline$\overline{801}$ & UNFPA \\
\hline 802 & UNDP \\
\hline 803 & UNHCR \\
\hline 804 & UNDP \\
\hline 805 & FAO \\
\hline 806 & $\overline{F A O}$ \\
\hline 807 & UNDP \\
\hline 808 & UNDP \\
\hline 809 & UNDP \\
\hline 810 & UNDP \\
\hline$\overline{811}$ & BBC AED / UNESCO \\
\hline$\overline{812}$ & BBC AED / UNESCO \\
\hline$\overline{813}$ & J.MILTON \\
\hline$\overline{814}$ & $\overline{F A O}$ \\
\hline$\overline{815}$ & FAO \\
\hline$\overline{816}$ & FAO \\
\hline 817 & UNOPS \\
\hline 818 & UNOPS \\
\hline$\overline{819}$ & UNHCR \\
\hline 820 & British Agencies Afghanistan Group \\
\hline 821 & A.R.I \\
\hline$\overline{822}$ & UNDP \\
\hline 823 & UNDP \\
\hline 824 & UNDP \\
\hline$\dot{8} 25$ & FAO \\
\hline 826 & United Nations \\
\hline 827 & $\mathrm{FAO}$ \\
\hline 828 & $\mathrm{FAO} / \mathrm{WHO}$ \\
\hline 829 & $\mathrm{FAO}$ \\
\hline 830 & $\mathrm{FAO}$ \\
\hline$\overline{831}$ & $\mathrm{FAO}$ \\
\hline 832 & FAO \\
\hline 833 & $\mathrm{FAO}$ \\
\hline
\end{tabular}

Trade and Marketing of Forest Products

LA RECHERCHE FORESTIERE

Reeducation of Wood Waste by Small Scale log Production and Conversation in Tropical High

Forest

Rambutan Cultivation

Dispatches

The Human Development Magazine

Afghanistan Refugees

Global Staff Forum 1998

FAO INVESTMENT CENTRE UPDATE

FAO INVESTMENT CENTER UPDATE

UPDATE

UNDP TODAY

Progress Against Poverty

The Human Development Magazine

$$
\text { نوى كور، نوى زوند }
$$

ACTES PROCEEDINGS ACTAS 8

نوى كور، نوى زوند

Gum Naval Stores: Turpentine and Rosin from Pineresin

Council

Use of the Construction Crane for Wood Extration on Mountainous Terrain

Agency List

Sub-Contracts By Agency

Mid Term Review of the 1998 Consolidated Appeal

Return Reconstruction

ARIANA RECONSTRUCTION INSTITUTE

Action Plan for Immediate Rehabilitation

Afghanistan Rehabilitation Steering Committee

Afghanistan Rehabilitation Steering Committee

Sericulture Development, Research and Training Afghanistan Project Findings and

Recommendations

UN Consolidated Inter-Agency Appeal for Emergency Humanitarian and Rehabilitation Assistance to Afghanistan

Joint Border Survey of the Spring Breading Areas of the Desert Locust in Baluchistan of the J.R Iran and Pakistan

Codex Alimentarius Commission FAO Quarterly Bulletin of Statistics

FAO Quarterly Bulletin of Statistics

Field Projects

Role of Acacia Species in the Rural Economy of Dry Africa and the Near Eas

twenty-third FAO Regional Conference for Latin America and the Carribbean

Third Government Consultation for Asia and the South West Pacific

\begin{tabular}{|l|l|}
\hline 1995 & 1 \\
\hline 1994 & 3 \\
\hline 1992 & 1 \\
\hline 1994 & 1 \\
\hline 1998 & 1 \\
\hline 1998 & 1 \\
\hline 1997 & 1 \\
\hline 1998 & 2 \\
\hline Jul-95 & 1 \\
\hline 1997 & 1 \\
\hline 1998 & 1 \\
\hline Apr-98 & 1 \\
\hline 1996 & 1 \\
\hline 1996 & 1 \\
\hline 1998 & 1 \\
\hline 1998 & 1 \\
\hline 1991 & 8 \\
\hline 1995 & 1 \\
\hline 1995 & 1 \\
\hline 1995 & 1 \\
\hline 1998 & 1 \\
\hline 1998 & 1 \\
\hline 1998 & 2 \\
\hline 1997 & 1 \\
\hline 1995 & 1 \\
\hline 1993 & 4 \\
\hline Feb-95 & 1 \\
\hline Jul-95 & 1 \\
\hline 1995 & 1 \\
\hline 1995 & 7 \\
\hline 1995 & \\
\hline 1995 & 1 \\
\hline 1995 & 1 \\
\hline 1993 & 1 \\
\hline 1995 & 1 \\
\hline 1994 & 1 \\
\hline 1983 & 1 \\
\hline & \\
\hline 1 & \\
\hline 1 & \\
\hline 1 & \\
\hline
\end{tabular}




\begin{tabular}{|c|c|c|c|c|}
\hline 834 & United States Department of Agriculture & Guide for Comprehensive EFNEP Unit Review & 1979 & 1 \\
\hline 835 & FAO & FAO Documentation & 1995 & 1 \\
\hline 836 & ADAB & $\begin{array}{l}\text { World Market Prospects for Vanilla, With Particular Reference to Prospects for Expanded } \\
\text { Production in Tonga }\end{array}$ & 1980 & 1 \\
\hline 837 & GTZ/FAO & Motivating Farmers for Action & 1986 & 1 \\
\hline 838 & TONSI ADENOLA AND FREDACHALE & Workshop Management & 1991 & $\overline{1}$ \\
\hline$\overline{839}$ & FAO/GTZ & Motivating Farmers for Action & 1986 & 3 \\
\hline$\overline{840}$ & FAO/UNDP & Seed Improvement Programme of Northern and Western Afghanistan & 1994 & 1 \\
\hline$\overline{841}$ & FAO & Rural Financial Markets Research in Progress No.5 & 1994 & 1 \\
\hline$\overline{842}$ & UNCHS & Afghanistan Immediate Action Plan. Human Settlements Sector & 1993 & 1 \\
\hline 843 & FAO & Standing Committee on Resource Research and Development & 1994 & 1 \\
\hline 844 & FAO & Aquaculture Production Statistics & 1995 & 1 \\
\hline 845 & FAO & Aquaculture in Marine Waters & 1997 & $1 \cdot$ \\
\hline$\overline{846}$ & FAO & Aquculture Status and Development Requirements in the Islamic Republic of Iran & 1995 & 1 \\
\hline 847 & FAO & Expert Consultation on Utilization and Conservation of Aquatic Genetic Resources & 1993 & 1 \\
\hline 848 & FAO & Living Marine Resources and Their Sustainable Development & 1995 & 1 \\
\hline 849 & FAO & Small Watershed Management In China & 1992 & 2 \\
\hline 850 & FAO & FAO Species Catalogue & 1993 & 1 \\
\hline 851 & FAO & Purse Seining Manual & 1994 & 1 \\
\hline 852 & FAO & Handling and Squid Jigging & 1992 & 4 \\
\hline 853 & FAO & Regional Expert Consultation on Aquacultrue Health Management in Asia and the Pacific & 1995 & 1 \\
\hline 854 & FAO & $\begin{array}{l}\text { Exective Committee of the Combustion for Controlling the Desert Locust in the Eastern Region of } \\
\text { its Distribution Area in Southwest Asia }\end{array}$ & 1995 & 8 \\
\hline$\underline{855}$ & FAO & $\begin{array}{l}\text { FAO Commission for Controlling the Desert Locust in the Eastern Region of its Distribution area in } \\
\text { South West Asia }\end{array}$ & 1994 & 1 \\
\hline 856 & FAO & Eighteenth FAO Regional Conference for Europe & 1992 & 1 \\
\hline 857 & FAO & Seventeenth FAO Regional conference for Africa & 1992 & 1 \\
\hline 858 & FAO & Eighteenth FAO Regional Conference for Africa & 1994 & 1 \\
\hline$\overline{859}$ & FAO & Twenty Second FAO Regional Conference for the Near East & 1994 & 1 \\
\hline 860 & FAO & Twenty Second FAO Regional Conference for Asia and the Pacific & 1994 & 1 \\
\hline 861 & National & Operating Instructions & $?$ & 1 \\
\hline 862 & $\mathrm{FAO}$ & Provisional Field Programme Reporting Annual & 1994 & 1 \\
\hline 863 & United Nations & Compendium of Project Activities & 1997 & 1 \\
\hline 864 & UNDP & Action Plan for Immediate Rehabilitation & 1993 & 1 \\
\hline 865 & AKBAR & The Role of NGOs in Afghanistan & 1995 & 1 \\
\hline 866 & AKBAR & Tears of Anguish & 1995 & 1 \\
\hline 867 & The Population Council. & Case Studies of the Impact of Large Scale Development Project on Women & 1979 & 1 \\
\hline 868 & T.B. Subasingh & Study of Income Generating Activities for Farm Women & 1978 & 1 \\
\hline 869 & International Women's Tribune Center, Inc. & Information Kit for Women in Africa & 1981 & 1 \\
\hline 870 & NFNC & Meeting Basic Needs & $?$ & 1 \\
\hline$\overline{871}$ & FAO & Massage No. 99 Programme & 1985 & 1 \\
\hline 872 & FAO / UNDP & Manual on Planning Implementation and Evaluation of Workshops & 1991 & 1 \\
\hline 873 & Märy Under Wood & Training Needs Identification & 1992 & 1 \\
\hline
\end{tabular}




\begin{tabular}{|c|c|c|c|c|}
\hline 874 & FAO & Assistance to Rural Broadcasting Afghanistan & 1977 & 1 \\
\hline 875 & FAO & Assessment of the Impact of an Integrated Development Project & 1994 & 1 \\
\hline 876 & FAO & $\begin{array}{l}\text { COMMISSION EUROPEAN CONSULTATIVE POURLES PEACHES DANSLES EAUX } \\
\text { INTERIEURES }\end{array}$ & 1993 & 1 \\
\hline 877 & FAO & $\begin{array}{l}\text { FESLM: AN INTERNATIONAL FRAME WOR FOR EVALUATING SUSTAINABLE LAND } \\
\text { MANAGEMENT }\end{array}$ & 1993 & 1 \\
\hline 878 & FAO & مجلس منظهه الاغذيه والزراعه & 1993 & 1 \\
\hline 879 & FAO & Conference & 1993 & 1 \\
\hline 880 & FAO & FAO Annual Review & 1991 & 30 \\
\hline 881 & ADCRP & BASELINE SURVEY & 1994 & 5 \\
\hline 882 & UNITED NATIONS & Summary of Security Procedures in Afghanistan (SSP) & 1995 & 4 \\
\hline 883 & UNITED NATIONS & $\begin{array}{l}\text { UN Consolidated Inter-Agency Appeal for Emergency Humanitarian and Rehabilitation Assistance } \\
\text { to Afghanistan }\end{array}$ & 1995 & 2 \\
\hline 884 & UNOCHA & A Continuing Humanitarian Emergency & 1995 & 3 \\
\hline 885 & UNITED NATIONS & Afghanistan An Enduring Tragedy & 1996 & 1 \\
\hline 886 & UNIVERSITY OF MELBOURNE & Work Attitudes and Organizational Change & 1980 & 1 \\
\hline$\overline{887}$ & UNIVERSITY OF MELBOURNE & Market Information on Rural Radio & 1980 & 1 \\
\hline 888 & UNDP et al & Rebuilding a War-Torn Society & $?$ & 32 \\
\hline 889 & UNDP et al & Rebuilding a War-Torn Society (Pushto) & $?$ & 7. \\
\hline 890 & FAO & The FAO Programme in Afghanistan 1988- 1997 & 1995 & 54 \\
\hline 891 & AREA & The Strategy $1997-2001$ & 1996 & 1 \\
\hline 892 & UNITED NATIONS & Summary of Security Procedures in Afghanistan (SSP) & 1997 & 1 \\
\hline 893 & UNITED NATIONS & Summary of Security Procedures in Afghanistan (SSP) & 1995 & 1 \\
\hline 894 & UNICEF & The Impact of Conflict on Children in Afghanistan & 1998 & 1 \\
\hline 895 & FAO et al & Participatory Processes for Integrated Watershed Management & 1997 & 1 \\
\hline 896 & BBC AED & New Home, New Life & $?$ & 1 \\
\hline 897 & UNOCHA & UNOCHA Mission & 1997 & 1 \\
\hline$\overline{898}$ & UNDP et al & Rebuilding a War-Torn Society & 1997 & 1 \\
\hline 899 & UNESCO / GTZ & Initiatives in Curriculum Design and Development & 1997 & 1 \\
\hline 900 & UNDP & Action Plan for Immediate Rehabilitation & 1993 & 4 \\
\hline 901 & UNDP & |فنانستان ... لـ سرستى تر خان بسياينى & 1994 & 1 \\
\hline 902 & FAO et al & World Decade for Cultural Development 1988 - 1997 & 1995 & 1 \\
\hline$\overline{903}$ & FAO & Freshwater and Aquaculture Contents Tables & 1995 & 4 \\
\hline 904 & FAO / NORAD & The Living Marine Resources of Namibia & 1993 & $1:$ \\
\hline 905 & FAO & Marine Mammals of the World & 1993 & 1 \\
\hline 906 & FAO & Fighting Hunger and Malnutrition & 1996 & 3 \\
\hline 907 & FAO & Social Communication in Nutrition & 1994 & 2 \\
\hline 908 & FAO / WHO & International Conference on Nutrition & 1992 & 2 \\
\hline 909 & FAO / WHO & Codex Alimentarius & 1994 & 6 \\
\hline 910 & FAO / WHO & Codex Alimentarius & 1993 & 1 \\
\hline$\overline{911}$ & FAO/WHO & Codex Alimentarius Commission & 1993 & 1 \\
\hline 912 & FAO/WHO & Codex Alimentarius Commission & 1995 & 1 \\
\hline
\end{tabular}




\begin{tabular}{|c|c|c|c|}
\hline FAO / WHO & List of Delegates and Observers & 1992 & 1 \\
\hline$\Gamma \mathrm{AO}$ & FAO Documentation & 1992 & 1 \\
\hline FAO & $\mathrm{RD}$ & 1996 & 1 \\
\hline FAO & FAO Documentation & 1993 & 1 \\
\hline FAO /WHO & Codex Alimentarius Commission & 1993 & 1 \\
\hline BRIDGET M. TAUMOEPEAU & Breast Feeding & $?$ & 1 \\
\hline FAO & Dimensions of Need & 1995 & 1 \\
\hline FAO / WHO & Nutrition & 1992 & 1 \\
\hline - FAO / WHO & Fats and Oils in Human Nutrition & 1994 & 1 \\
\hline UNOCHA & Mine Clearance Programme & 1994 & 1 \\
\hline UNDP / FAO & Consultancy Mission & 1994 & 1 \\
\hline FAO & Structural Adjustment and Rural Poverty in Developing Countries a Survey & 1995 & 1 \\
\hline UNDCP & The Impact of Drugs on the Peace Process and Rehabilitation in the Country & 1995 & 1 \\
\hline FAO & Research and Technology Development Service & 1998 & 1 \\
\hline UNDP & Children in Families Affected by the HIV Epidemic: & 1993 & 1 \\
\hline UNDP & Young Women: Silence, Susceptibility and the HIVEPIDEMIC & 1993 & 1 \\
\hline UNDP & The Role of the Law, Ethics and Discrimination & 1993 & 1 \\
\hline UNDP & Women the HIV Epidemic and Human Rights & 1993 & 1 \\
\hline UNDP & Behavior Change & 1993 & 1 \\
\hline UNDP & Placing Women At the Center of the Analysis & 1993 & 1 \\
\hline UNDP & Sharing the Challenge of the HIV Epidemic & 1993 & 1 \\
\hline UNDP & People Living with HIV & 1993 & 1 \\
\hline UNDP & FEMALE GENITAL HEALTH AND THE RISK OF HIV TRANSMISSION & 1993 & 1 \\
\hline UNDP & ECONOMIC IMPACT OF THE HIV EPIDEMIC & 1993 & 1 \\
\hline UNDP & THE HIV EPIDEMIC AND DEVELOPMENT & 1993 & 2 \\
\hline WHO & Hope & 1996 & 1 \\
\hline UNDP & Governance and IIV & $?$ & 2 \\
\hline UNDP & HIV, ETHICS, LAW AND HUMAN RIGHTS & 1997 & 1 \\
\hline UNDP & NUTRITION, HEALTH AND EDUCATION FOR ALL & 1994 & 1 \\
\hline ODA & OUR CLIENT THE SMALLHOLDER & 1992 & 2 \\
\hline FAO & FIGHTING HUNGER AND MALNUTRITION & 1996 & 1 \\
\hline $\mathrm{FAO}$ & SYNTHESIS OF THE TECHNICAL BACKGROUND DOCUMENTS & 1996 & 1 \\
\hline FAO & LIST OF SELECTED ARTICLES (Losa) & 1995 & 1 \\
\hline FAO & Guide Methdologique Des Interventions Dans La Communication Sociale en Nutrition & 1993 & 1 \\
\hline FAO & الدوتمر الاقليمى الحادى والعشرين لمنظمه الاغذيه حلزراعه الشرق الادنى & 1992 & 1 \\
\hline S.B.R NIKAHETIYA et al - & GARDENING FŌR HEALTH & 1983 & 1 \\
\hline FAO & International Conference on Nutrition & 1992 & 3 \\
\hline FAO & Casa Gazette & 1995 & 2 \\
\hline FAO & Casa, Gazette & Jun-95 & 1 \\
\hline FAO & Casa & 1995 & 11 \\
\hline FAO & Casa & 1996 & 7 \\
\hline FAO & Casa & 1998 & 4 \\
\hline
\end{tabular}




\begin{tabular}{|c|c|c|c|c|}
\hline 959 & FAO & Manuels Sur Le Controle De La Qualite Des Produits Alimentaires & 1992 & 1 \\
\hline 560 & $\mathrm{FAO}$ & The Burden of Proof in Natural Resources Legislation & 1998 & 1 \\
\hline 961 & FAO & FAO Documentation & 1992 & 1 \\
\hline 962 & FAO & FAO Documentation & 1993 & 1 \\
\hline 963 & FAO & حاله الاغذيه والزراعه & 1992 & 1 \\
\hline 964 & FAO & حاله الاغذيه والزراعه & 1991 & 1 \\
\hline 965 & FAO & حاله الاغذيه والزراعه & 1990 & 1 \\
\hline 966 & FAO & Summary of the International Conference on Nutrition & 1993 & 2 \\
\hline 967 & FAO & Internation Rice Research Institute & 1993 & 5 \\
\hline 968 & FAO / UNDP & SUPPORT TO VETERINARY CLINICS IN AFGHANISTAN & 1994 & 1 \\
\hline 969 & United Nations & $\begin{array}{l}\text { APPEAL FOR EMERGENCY HUMANITARIAN AND REHABILITATION ASSISTANCE TO } \\
\text { AFGHANISTAN }\end{array}$ & 1995 & 1 \\
\hline 970 & FAO & Directory of Governmental and Quasi-Governmental Rice Trading Agencies & 1994 & 6 \\
\hline 971 & FAO & World Appeared Fibber Consumption Survey & 1992 & 2 \\
\hline 972 & FAO & Amenagement et Conservation Des Forets Denses en Amerique Tropical & 1992 & 1 \\
\hline 973 & FAO & Les Raisons Du Succes ou de L'echec Des Projets de Conservation des Sols & 1993 & 1 \\
\hline 974 & FAO & Guide Pratique D'amenagement des Bassins Versans & 1993 & 1 \\
\hline 975 & FAO & La Reglementation de la Peche au Filet Maillant derivant en haute mer & 1992 & 1 \\
\hline 976 & FAO & Treaties Concerning the Non-Navigational Uses of International Water Courses - Europe & 1993 & 1 \\
\hline 977 & FAO & Biogas Processes for Sustainable Development & 1992 & 1 \\
\hline 978 & FAO & Technology of Production of Edible Flours and Protein Products From Soybeans & 1992 & 1 \\
\hline 979 & FAO & La Technologie des Fromages au Lait de Dromadaire & 1993 & 1 \\
\hline 980 & FAO & Recommendations Concernant Le Marquage des Engins de Peche & 1993 & 1 \\
\hline 981 & FAO & Pulp and Paper Capacities & 1995 & 1 \\
\hline 982 & FAO & FIELD CROP PROTECTION IN NORTHERN AFGHANISTAN & 1995 & 3 \\
\hline 983 & FAO & $\begin{array}{l}\text { Exective Committee of the Commission for Controlling the Desert Locust in the Eastern Region of } \\
\text { its Distribution Area in South-West Asian }\end{array}$ & 1995 & 1 \\
\hline 984 & Afghan Disabled Society & 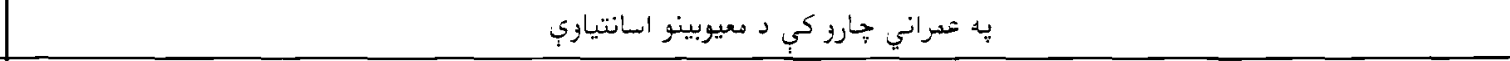 & 1994 & 2 \\
\hline 985 & UNDP / UNOPS & Afghanistan Rural Rehabilitation Programme & 1998 & 1 \\
\hline 986 & SCA & SCA in 1997 & 1997 & 1 \\
\hline 987 & EU & VETERINARY MALUMAT & Jul-98 & 2 \\
\hline 988 & $E U$ & وترنري معلومات & Feb-98 & 3 \\
\hline
\end{tabular}




\section{Food}

\begin{tabular}{|c|c|c|c|c|}
\hline 989 & TFAO & Foodcrops and Shortages & 1993 & 1 \\
\hline 990 & $\mathrm{FAO}$ & Foodcrops and Shortages & 1995 & 1 \\
\hline 991 & FAO / WHO & Pesticide Residues in Food 1994 & 1995 & 1 \\
\hline 992 & FAO & Foodcrops and shortages & 1996 & 1 \\
\hline 993 & FAO & Foodcrops and shortages & 1995 & 1 \\
\hline 995 & FAO & Foodcrops and Shortages & 1995 & 1 \\
\hline 996 & FAO & Foodcrops and Shortages & 1994 & 1 \\
\hline 997 & U.S. Department of Agriculture & Food and Nutrition & Mar-71 & 2 \\
\hline 998 & U.S. Department of Agriculture & Food and Nutrition & 1970 & 1 \\
\hline 999 & FAO & Food Outlook & 1995 & 1 \\
\hline 1000 & FAO & Cost - Benefit Aspects of Food Irradiation Processing & 1993 & 2 \\
\hline 1001 & FAO & World Food Summit & Nov-96 & 1 \\
\hline 1002 & FAO & Integrated Crop and Food Production in Afghanistan & Apr-97 & 2 \\
\hline 1003 & FAO & Telefood & $?$ & 1 \\
\hline 1004 & FAO & Pesticide Residues in Food 1993 & 1993 & 1 \\
\hline 1005 & FAO & Pesticide Residues in Food 1992 & 1993 & 2 \\
\hline 1006 & FAO $/$ WHO & Pesticide Residues in Food 1991 & 1991 & 3 \\
\hline 1007 & FAO & Food Crops and Shortages & 1995 & 1 \\
\hline 1008 & FAO & Foodcrops and Shortages & 1993 & 1 \\
\hline 1009 & FAO & Food Outlook & Feb-93 & 1 \\
\hline 1011 & FAO & How The International Community Can Promote Food Security & 1995 & 1 \\
\hline 1012 & FAO & Integrated Crop and Food Production in Afghanistan & 1997 & 1 \\
\hline 1013 & IPCS / FAO & $\begin{array}{l}\text { Summary of Evaluations Performed by the Joint FAO / WHO Expert Committee on Food Additives } \\
\text { (JECFA) }\end{array}$ & 1994 & 1 \\
\hline 1014 & FAO & Aquculture Nutrition and Food Technology & 1995 & 1 \\
\hline 1015 & FAO / WHO & Application of Risk Analysis to Food Standards Issues & 1995 & 1 \\
\hline 1016 & FAO & Integrated Crop and Food Production in Afghanistan & 1997 & 2 \\
\hline 1017 & FAO & The Special Programme for Food Security & $?$ & 1 \\
\hline 1018 & FAO & Assurance of Seafood Quality & 1994 & 2 \\
\hline 1019 & FAO & Land Food and Population & 1983 & 2 \\
\hline 1020 & FAO $/$ WHO & التخذيه & 1992 & 5 \\
\hline 1021 & FAO & الاستعراض المسنوي لنشاطات & 1992 & 5 \\
\hline 1022 & FAO & Issues in Rural Poverty Employment and Food Security & 1995 & 4 \\
\hline 1023 & FAO & World Food Summit & 1996 & 4 \\
\hline 1024 & FAO & low-cost Urban Food Distribution Systems in Latin America & 1994 & 1 \\
\hline 1025 & FAO & Food Outlook & Mar-93 & 2 \\
\hline
\end{tabular}




\begin{tabular}{|c|c|c|c|c|}
\hline 1026 & FAO & Food Outlook & Dec-93 & 7 \\
\hline 027 & FAO & Food Outlook & Jun-95 & 1 \\
\hline 1028 & FAO & Food Outlook & Dec-95 & 1 \\
\hline 1029 & FAO & Food Outlook & Feb-96 & 1 \\
\hline 1030 & FAO & Food Outlook & Apr-96 & 1 \\
\hline 1032 & $\mathrm{FAO} / \mathrm{WHO}$ & Compendium of Food Additive Specifications & 1992 & 14 \\
\hline 1033 & FAO & Food Losses Due to Non-Infectious and Production Diseases in Developing Countries & 1993 & 1 \\
\hline 1034 & WFP & تقرير الدوره الرابعه والثلاثين للجنه سياسات المغونه النذائيه و برامجها & 1992 & 1 \\
\hline 1035 & FAO & Food For Consumers: Marketing, Processing and Distribution & 1995 & 1 \\
\hline 1037 & FAO & Compendium of Food Consumption Statistics From Household Surveys in Developing Countries & 1993 & 1 \\
\hline 1038 & FAO / WHO & Pesticide Residues in Food 1994 & 1995 & 1 \\
\hline 1039 & FAO & Issues in Rural Poverty, Employment and Food Security & 1995 & 1 \\
\hline 1040 & WHO/FAO & Food, Water and Family Health & 1994 & 1 \\
\hline 1041 & FAO & World Food Summit & 1996 & 1 \\
\hline 1042 & FAO & FOOD FOR ALL & 1996 & 1 \\
\hline 1043 & FAO / PARC & Integrated Pest Management IN Food Grain & 1992 & 1 \\
\hline 1044 & UNIFEM & Women's Roles in the Innovation of Food cycle Technologies & 1994 & 1 \\
\hline 1045 & FAO & Food and Nutrition in the Management of Group Feeding Programmes & 1993 & 1 \\
\hline 1048 & FAO & Manual of Food Quality Control & 1993 & 4 \\
\hline 1049 & FAO & Manual of Food Quality Control & 1994 & 1 \\
\hline 1050 & FAO & Food Aid in Figures & 1992 & 15 \\
\hline
\end{tabular}

